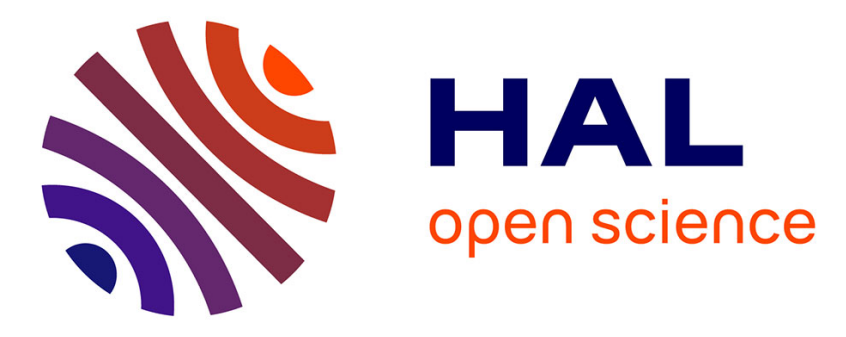

\title{
Ecological risk assessment of urban and industrial systems: A review.
}

Yves Perrodin, Clotilde Boillot, Ruth Angerville, Gilles Donguy, Emmanuel Evens

\section{- To cite this version:}

Yves Perrodin, Clotilde Boillot, Ruth Angerville, Gilles Donguy, Emmanuel Evens. Ecological risk assessment of urban and industrial systems: A review.. Science of the Total Environment, 2011, 409, pp.5162-5176. 10.1016/j.scitotenv.2011.08.053 . halsde-00642679

\section{HAL Id: halsde-00642679 \\ https://hal.science/halsde-00642679}

Submitted on 11 Dec 2018

HAL is a multi-disciplinary open access archive for the deposit and dissemination of scientific research documents, whether they are published or not. The documents may come from teaching and research institutions in France or abroad, or from public or private research centers.
L'archive ouverte pluridisciplinaire HAL, est destinée au dépôt et à la diffusion de documents scientifiques de niveau recherche, publiés ou non, émanant des établissements d'enseignement et de recherche français ou étrangers, des laboratoires publics ou privés. 


\title{
Ecological risk assessment of urban and industrial systems: A review
}

\author{
Yves Perrodin $^{\mathrm{a}, *}$, Clotilde Boillot $^{\mathrm{a}}$, Ruth Angerville ${ }^{\mathrm{a}, \mathrm{b}}$, Gilles Donguy ${ }^{\mathrm{a}}$, Evens Emmanuel ${ }^{\mathrm{b}}$ \\ a Université de Lyon, ENTPE, CNRS, UMR 5023, 69518 Vaulx-en-Velin, France, ${ }^{\text {b }}$ Université Quisqueya, Laboratoire LAQUE, BP 796, Port-au-Prince, Haïti
}

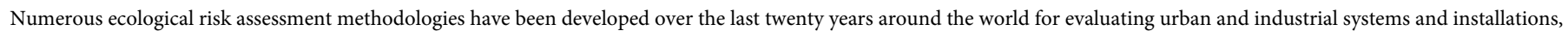

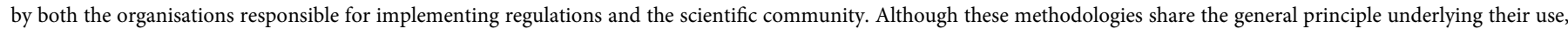

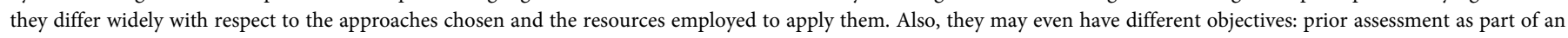

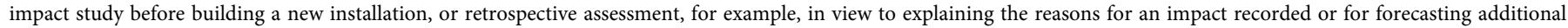

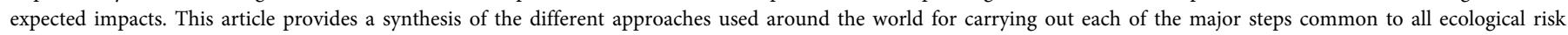

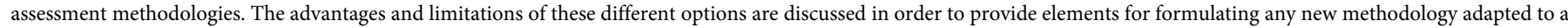

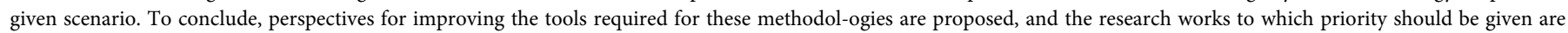
identified.

\section{Introduction}

The first Ecological Risk Assessment (ERA) methodologies emerged at the beginning of the 1990s with dawning awareness of the risks liable to impact ecosystems when they are exposed to substances of anthropic origin. In 1992, the United States EPA proposed an initial methodological guide for managing contaminated industrial sites. Following a certain number of works, especially those of Suter (1993), this guide was improved to become "The Guideline for Ecological Risk Assessment" (US EPA, 1998) which has now become the reference regarding ERA (Bermond, 2002; Hayet, 2006; Rivière, 1998). Since then, this guide has been revised by many countries and adapted to manage their polluted sites (CEAEQ 1998; Environment Agency of United Kingdoms, 2003).

In addition, methodologies have been formulated to evaluate ecological risks linked to other problems. Mention can be made of the methodology drawn up by the European Union to evaluate risks relating to chemical substances placed on the market (ECB, 2003; Environment Agency of United Kingdoms, 2003), and French works on the assessment of ecotoxicological risks linked to dumping dredged sediments (Babut and Perrodin, 2001; CETMEF, 2001), on the assessment of the ecocompatibility of using wastes (ADEME, 2002; Perrodin et al., 2000), and on the assessment of ecotoxicological risks linked to hospital effluents (Boillot et al., 2008, 2006; Emmanuel et al., 2005b).

Lastly, several studies incorporating partial syntheses of methodologies used internationally for evaluating risks have been published (Hayet, 2006; RECORD, 2006).

This article first presents a synthesis of the different approaches used internationally for performing each of the four main phases common to all ecological risk assessments. The advantages and limitations of these different options are then discussed, in view to formulating methodologies in areas not yet covered by these decision aids. To conclude, perspectives for improving the tools required for these methodologies are proposed and the research works that should be given priority are identified.

\section{Global approach and presentation of the four phases of an ERA}

Most ERA methods formulated at international level are implemented with four main phases: (1) the formulation of the problem, (2) the characterisation of exposures (3) the characterisation of effects, and lastly, (4) the characterisation of the risk itself.

It is noteworthy that the characterisation of exposures and that of effects are performed in parallel but are in constant interaction (Babut and Perrodin, 2001; Rivière, 1998).

\subsection{The formulation of the problem}

The problem formulation phase is fundamental. It comprises investigation and technical options, following which a highly precise plan of actions has to be established (identification of the data to be collected, the measurement and assessment techniques to be used, as well as the framework of interpretation) to carry out the subsequent phases of the ERA (Babut and Perrodin, 2001; Bermond, 2002; Emmanuel et al., 2004; Rivière, 1998).

\subsection{The characterisation of exposures}

Exposure characterisation aims at determining the probability of spatial-temporal contact between pollutants and target populations (receivers) (US EPA, 1998). It includes the analysis of sources of pollutants, the transfer of the latter from their sources, and the distribution of pollutants in the environment. Exposure depends on both the concentrations of pollutants in the environment and the characteristics and behaviour of the target organisms. Finally, it takes into account the doses absorbed by target populations. This analysis can be performed by using theoretical models of pollutant transfer and/or pollutants and/or on the basis of experimental results (Babut and Perrodin, 2001).

This phase results in the determination of one or more values characterising exposure. In the case of a "substance-based" approach, the term Predicted Environmental Concentration (PEC) is used, whereas in a "matrix" approach, the notion of percentage of polluted source matrix in the environment is employed (Donguy and Perrodin, 2007). In both cases the parameter concerned is the concentration of a substance that can be expected in the environment following different inputs. Determining these values can prove complex, since account must be taken of a considerable number of phenomena liable to occur during transit via different pathways: dilution, evaporation, biodegradation, bio-accumulation, change of speciation of substances, the characteristics of the ecosystem, etc. Exposure can also be direct or indirect, short or long term, or variable or invariable through time (Donguy and Perrodin, 2006; RECORD, 2006; Rivière, 1998).

\subsection{The characterisation of effects}

This phase entails defining to what extent the organisms of the target ecosystem are significantly sensitive to the pollutants to which they are exposed (Donguy and Perrodin, 2006). This step is mainly based on biological approaches that include bioassays. It results in the acquisition of different values of ecotoxicological effects (NOEC, CE20, CE50, etc.) making it possible to calculate, after applying an extrapolation factor, the value of absence of significant effect on the whole of the target ecosystem. This value is commonly known as the Predicted No Effect Concentration (PNEC).

\subsection{The characterisation of the risk itself}

The characterisation of risks is based on the results obtained during the previous phases. The basic principle is to compare the level of presence of one or more pollutants within the target ecosystem, and the severity of its, or their, effect(s) on the target ecosystems. Ideally, an uncertainty calculation is performed and linked to the result.

\section{Detailed approach of the four major phases of the ERA}

\subsection{Problem formulation phase}

This phase generally includes the following three steps (US EPA, 1998):

Step 1: Detailed description of the context and integration of the available data. 
The aim of this step is to clarify the scenario studied. It entails identifying the sources of pollutant emissions, the pathways by which transfer occurs and the target ecosystems on the basis of existing knowledge (geographic and temporal limits, pollutants, targets, potential vectors, etc.).

Step 2: Selection of assessment parameters and the formulation of the conceptual model.

This entails selecting the elements of target ecosystems to be protected in relation to the scenario. The conceptual model corresponds to the medium used for communication between the assessors and decision-makers, it is an approach that provides an integrated view of the scenario: selection of pollutants, emission sources, transfer pathways, target ecosystems to be protected, ratios of dilution by weight and volume, spatial and temporal scales, bioassays and the assessment endpoints considered, and the approaches used.

Step 3: Formulation of an analysis plan.

This is the final step of the formulation phase which underlines the requirement to programme the assessment and interpretation of data before starting the analyses (Emmanuel et al., 2004).

The type of approach used to characterise ecotoxicological effects is selected during the problem formulation phase (a substance-based approach or a matrix-based one). The substance-based approach relies on the physicochemical analysis of pollutants (e.g., lead, PCB, drugs, etc.) and uses values taken from international ecotoxicological databases, whereas the matrix-based approach considers the source of the pollutants in mixture as a whole (e.g., effluents, wastes, sediments, etc.) which is subjected to bioassays (Donguy and Perrodin, 2007).

\subsection{Exposure characterisation phase}

As specified above, exposure can be characterised according to two main approaches, one based on "substance" and the other on "matrix". The substance-based approach is the more classical of the two and permits, generally without great difficulty, calculating the level of exposure of each of the organisms of the target ecosystem to each of the main pollutants present. The matrix-based approach is more complex but more realistic, not only because it allows integrating the behaviour of pollutants in mixture and within their real matrix, but also because it takes better account of phenomena that may radically change the exposure of organisms such as exposure to minor pollutants not identified when formulating the problem, exposure to pollutants adsorbed totally or partially on fine particles and/or colloids, major pollutants whose availability is barred by the physicochemical conditions of the environment, etc.

\subsubsection{Assessment of exposure by the substance-based approach}

Evaluating exposure by using a substance-based approach first requires determining environmental concentrations following the study of transfers between the source or sources of the pollution and the target ecosystems and then using the data acquired to characterise the actual exposure of the organisms.

\subsubsection{Characterising environmental concentrations}

The characterisation of environmental concentrations results from the different phenomena occurring between the sources of pollution and the target ecosystems, in particular during the transfer of pollutants in the soils of the site concerned. This characterisation requires identifying and ranking the main hydrodynamic mechanisms involved, such as convection, diffusion and dispersion (De Smedt and Wierenga, 1979; Jury and Roth, 1990; Ma and Selim, 1995; Ma and Selim, 1996; Nielsen et al., 1986; Parker and Van Genuchten, 1984), taking account of the chemical interactions of the pollutants with the soil, such as adsorption, chelation and precipitation (Gaudet et al., 1977; Korte et al., 1976; Miller and Benson, 1983; Neville et al., 2000; Yong et al., 1992b), as well as taking account of pollutant transfer facilitated by particles and colloids (Corapcioglu and Jiang, 1993; Grolimund and Borkovec, 2001; Hahn et al., 2004; Massoudieh and Ginn, 2008; Mc Gechan and Lewis, 2002). This phase brings into play a wide range of models (Bai et al., 1997; Miller and Benson, 1983; Selim et al., 1999; Wen et al., 1998; Zurmühl and Durner, 1996) amongst which can be distinguished deterministic and stochastic models. Deterministic models use known input parameters (for example, water height, description of the environment), likewise for the equations characterising the modalities of pollutant transfers (for example, Darcy's law), and provide a result that can be compared with real measurements for the purposes of calibration. This type of model focuses on detailed understanding of the mechanisms involved. Stochastic models use large data sets as inputs and provide a probability as a result.

These models have given rise to different reviews of states of the art in different contexts (Hinz et al., 1998; Köhne et al., 2009; Mills et al., 1991; Sardin et al., 1991; Spencer et al., 1982; Travis and Etnier, 1981; Yong et al., 1992a) that describe their scopes of application, performances and limitations. The limitations most usually mentioned include:

- failure to take into account interactions between substances during their transport,

- failure to take into account biodegradation and/or the volatilisation of substances during their transport,

- the heterogeneity of the media crossed that can lead to preferential paths not taken into account in the models.

In the strict framework of risk assessment, the difficulty resides in optimising the interface between the "outputs" of these models and the "inputs" of biological models. This is true regarding the theoretical level (linking models in cascade), that of the compatibility of temporal scales (respective characteristic times of bio-physicochemical and ecological processes), the spatial level (meshing) and the practical and experimental level.

\subsubsection{Characterising organism exposure}

This is one of the most complex phases in ecological risk assessment. Improving it depends in particular on:

- improving toxicokinetic models (assessment of the internal dose of a toxic substance on the basis of environmental concentrations),

- improving knowledge on bio-accumulation in trophic chains,

- and, as is often forgotten, enhancing knowledge on the characterisation of the behaviour of organisms in response to a pollutant emission (e.g., the response of mobile organisms to instantaneous peaks of transient pollution due to leaks).

\subsubsection{Assessment of exposure by the matrix-based approach}

3.2.4.1. Characterisation of pollutant emissions by solid matrixes. The behaviour of single or mixed pollutants in a solid matrix can be studied by a variety of tests. The main tests used to predict the emission of pollutants to receiving environments are the following (Blanchard, 2000; Jauzein et al., 1999):

- Batch tests (suspension of the polluted solid matrix tested in a leaching solution in a closed reactor, with a usual liquid/solid ratio of 1/10) (EN, 12457, 2003; ISO/TS, 21268-1 21268-2 21268-3, 2007). These tests highlight the fraction of pollutants mobilised by diffusion and, when monitoring the evolution of concentration as a function of time in the liquid fraction, make it possible to determine the chemical kinetics of the solubilisation of chemical species trapped in the solid matrix. In particular, it is possible to perform selective extractions 
by modifying the quality of the leaching solution and obtain indications on the speciation of the chemical elements retained in the solid matrix;

- Column percolation tests. These tests permit coupling convective and dispersive phenomena that play a role in the transfer of pollutants in porous media subject to flowing water under natural conditions. The relation between liquid and solid phases is often closer to that effectively observed in reality. The principle is simple: the material to be tested is placed in a column, usually cylindrical, with a fixed dry density. A leaching solution is then injected into the column from either the top or bottom. The solution collected at the outlet of the column, called the "percolate", is fractionated and analysed. The varying concentrations of the different elements sought as a function of time result from physicochemical and hydraulic processes taking place in the column. In up-flow columns the fluid circulates from the bottom of the column to the top, "drowning" the material and saturating it completely (all the pores are filled by the leaching solution). Down-flow columns, in which the material is "sprayed" from above by the leaching solution, are used to simulate non saturated environmental conditions. In this case, it is necessary to determine the fraction of the pore volume effectively filled with water. These dynamic tests are widely used on solid wastes and polluted soils. Column tests are used in many countries and are now subject to international standards (CEN/TS, 14405, 2004; ISO, 18772, 2007; ISO/TS, 21268-1 21268-2 21268-3, 2007).

3.2.4.2. Characterising transfers of pollutants from the source to target ecosystems. In the case of a matrix-based approach, characterising the transfer of pollutants from the source to target ecosystems consists in studying the behaviour of percolates or leachates resulting from prior experimental studies performed on the transfer soils concerned. The tools used are the same as described previously (especially percolation columns), although in this case clean transfer soil is placed inside the column, after which the leachate or percolate produced beforehand is injected. In this case the retention of pollutants by the initially clean soil is estimated on the basis of the modified leachate collected at the outlet. These modified percolates are then used for exposing organisms under the conditions set out by the scenario.

3.2.4.3. Characterising organism exposure. Characterising the exposure of organisms by using experimental microcosms and mesocosms frees researchers from several of the limitations mentioned previously. These systems are sometimes designed with the sole intention of characterising organism exposure (measured with exposure biomarkers), and sometimes designed to permit characterising both exposure and its effect on organisms (see further on).

\subsection{Effects characterisation phase}

\subsubsection{Typology of effect characterisation strategies}

We saw previously that the substance-based approach focuses on the physicochemical analysis of the source matrix (waste, effluent, etc.) and is based on the different pollutants (lead, PCB, chlorine, etc.) it contains, whereas the bioassay approach takes the source matrix into account as a global entity. Furthermore, each of these two approaches can be subdivided into two categories:

- the substance-based approach can be considered from two angles: the single substance-based approach, that we call the substance approach, and the substance with combined effects approach. The substance approach takes into account the effects of each of the pollutants independently, whereas the substance with combined effects approach is based on all the pollutants identified and considers their combined effects on target ecosystems.

- the bioassay approach can also be considered from two angles: a battery of bioassays is used to analyse the effects of pollutants by implementing a battery of monospecific bioassays (bioassays with only one species), whereas the multispecific bioassay approach is based on bioassays that use several species at the same time and which permit testing higher levels of biological organisation.

Ultimately, four effect characterisation strategies result from these considerations:

- the "single substance" approach,

- the "substances with combined effects" approach,

- the "battery of bioassays" approach,

- the "multispecific bioassays" approach.

These four types of approach satisfy different concerns, though can also be used in synergy to obtain more global understanding of a problem. According to Simon et al. (1998), an integrated approach is needed to determine the toxicity of an effluent for an ecosystem. The real difficulty in choosing a type of approach stems from the desire of decision-makers to have available a tool that responds to a set of criteria and that allows defining whether the health of receiving ecosystems is affected or not. According to calow (1993), the ideal response would be a system that takes into account the following five performance criteria: ecological realism, repeatability, reproducibility, sensitivity, reliability (precision) and robustness (ease of interpretation). A priori, no test is available as yet that fulfils all these criteria, thus leading to the need for compromise.

\subsubsection{The single substance approach}

The single substance approach is the most classical means of characterising effects. It is distinguished by three separate steps: the identification of potential pollutants (mention is also made of risk tracers), searching for effect values and, finally, the calculation of the PNEC to conclude the approach.

The first step consists in the physicochemical characterisation of the pollutant or pollutants concerned and it is sometimes performed before the ERA, when assessing the risks. Whatever the case, the difficulty lies in choosing the parameters to be analysed (due to the risk of omitting a potentially important stressor). The choice of trace pollutants takes into account the desire to cover a range of specific or diversified pollutants (organic or mineral, chemical or biological, etc.) relating to the scenario studied. It is also vital to select pollutants acting via different exposure pathways in the scenario (Perrodin et al., 2004).

The second step calls on international ecotoxicity databases. Exhaustive searching of existing ecotoxicity data is performed for each of the tracers selected, by using databases accessible on the Internet, specialised software applications such as TerraSys (Trépanier, 2005) and the scientific literature.

The last step consists in calculating the PNEC for each of the tracers, by dividing the effect factor obtained for the most sensitive organism (for each stressor) by an extrapolation factor (also called security or uncertainty factor).

Indeed, extrapolating the effects obtained with a few species to an entire ecosystem involves several uncertainties that have been identified by INERIS (1999) and Forbes and Calow (2002b):

- inter-investigation and inter-laboratory variations,

- intra-specific variations linked to the physiological status of individuals of the same species,

- inter-specific variations resulting from differences of sensitivity between different species of an ecosystem to a substance,

- extrapolations of toxicity from the short to the long term. Sublethal effects can occur in the long term and place a population at risk, without being detectable in the short term,

- extrapolations of laboratory data that do not take into account the initial state of the ecosystem. Additive, synergistic and antagonistic effects due to the presence of other substances in the environment 
may play a role and modify the effects of the substance tested in the biocenosis.

The importance of extrapolation factors depends on the quantity of information available for the ecosystem. Therefore if the ecotoxicity data for species belonging to different taxonomic groups and trophic levels exist, the extrapolation factor will be lower than in the case where only a few data are available (INERIS, 1999). Lastly, it is noteworthy that the values of extrapolation factors vary according to author (Forbes and Calow, 2002a), and that those of the European Chemicals Bureau, depending on the available ecotoxicological data, are those most often used in Europe (ECB, 2003):

- at least one $C(E) L 50$ of a short test for each of the three trophic levels (fish, invertebrates and algae) available $\rightarrow$ extrapolation factor $=1000$,

- an NOEC of a long term test (fish or invertebrates) available: extrapolation factor $=100$,

- two NOEC of long term tests with two species representative of two trophic levels (fish and/or invertebrates and/or algae) available $\rightarrow$ extrapolation factor $=50$,

- three NOEC of long term tests for at least three species representing three trophic levels (fish, invertebrates, algae) available $\rightarrow$ extrapolation factor $=10$,

- field data or model ecosystem available $\rightarrow$ extrapolation factor assessed case by case.

It is sometimes possible to avoid the step of seeking effect factors and replace it with "pre-calculated" PNEC values for certain tracers. The INERIS environmental database (2006) provides such values in France. This database stems from approaches taken by different countries and organisations (European Union, OECD, France - INERIS, etc.), to evaluate the environmental risks incurred by various chemical substances. It is responsible for collecting the data extracted from different files (risk assessment reports on substances on the ECB site, SIDS reports (Screening Information DataSet) on the OECD site, etc.) and making them available online (physicochemical and ecotoxicological characteristics).

Overall, the substance-based approach appears simplistic and has often been criticised. It does not take into account the combined effects of substances, nor does it provide a full or efficient assessment of their bio-availability.

\subsubsection{The substances with combined effects approach}

In most case studies, no pollutant acts alone. This is why many authors insist on the need to obtain global understanding of pollutions and take into account the combined effects of mixed substances. The "substance with combined effects" approach differs from the single substance approach by the need to carry out a preliminary study of the combined effects of the substances involved in the ERA scenario studied (or by carrying out a synthesis of existing data if sufficient). According to the types of combined effects identified, the latter can be taken into account in the calculation of a global PNEC relating to the mixture of substances composing the pollution matrix.

In the case of antagonistic of synergistic effects, combined effects can only be included in the global PNEC qualitatively.

\section{Table 1}

Classification for a mixture of two substances (Plackett and Hewlett, 1952).

\begin{tabular}{lll}
\hline & Similar joint action & Dissimilar joint action \\
\hline Non-interactive & Simple similar & Independent \\
& Or additivity of concentrations/ & or additivity of effects/ \\
& doses & responses \\
& Or Loewe additivity & Or Bliss independence \\
Interactive & Complex similar & Dependent \\
& Or Loewe synergism/ & Or Bliss synergism/ \\
& antagonism & antagonism \\
\hline
\end{tabular}

\subsubsection{Preliminary definitions}

The concepts and theories underlying toxicological studies of mixtures have been established according to those used in a very similar discipline, namely, toxicology. The first concept was formulated by Loewe and Muischnek (1926), and is based on the fact that when substances are in mixture the concentrations of their effects accumulate (Greco et al., 1995). Effects prove to be additive when one substance acts as the dilution of another, i.e. the ecotoxicity of the mixture is proportional to the ecotoxicity and to the concentration of the substances in mixture (Altenburger et al., 1990).

In 1939, Bliss introduced the notion of substance action site (on organisms). Substances act on one or more action sites to produce one or more effects (inhibition of an enzyme, inhibition of muscular activity, etc.). Consequently, a substance can act and produce an effect independently in a mixture. Each substance therefore contributes to a response or a global effect. This theory is based on the study of the modes and mechanisms of action of substances. These modes and mechanisms are responsible for the specific way in which a substance causes an effect on an organism (Suter, 2006).

Bliss (1939) therefore developed the first classification of combined effects that identifies three types of mode of action of substances in mixture:

(i) Independent joint action: the constituents act on different action sites and the biological response of a constituent is not influenced by that of another;

(ii) Similar joint action: the constituents act independently on the same action sites and the biological response of a constituent is not influenced by another;

(iii) Synergistic action: the response of a mixture cannot be understood through the isolated responses of constituents but depends on their combined effects (Mercier, 2002; Yang, 1994).

On the basis of the results of Bliss' works (1939), Plackett and Hewlett (1952) then formulated a classification for a mixture of two substances (Table 1) that is still used today.

In this approach "similar joint action" means that the substances act on the same action site and while "dissimilar" means that they act on different sites. "Non-interactive" means that the biological response of a substance is not influenced by that of another (in other words the interaction is additive), "interactive" means that the biological response of a substance is influenced by that of the other and that the effects are therefore more than additive (synergistic) or less than additive (antagonistic).

\subsubsection{Models for determining combined effects in the ecotoxicity of mixtures}

Certain studies distinguish two types of mixtures: simple mixtures whose compounds are identified and low in number (less than 10) and complex mixtures with a large number of compounds (more than 10). Regarding the second type of mixture, Feron et al. (1995) recommended isolating ten of the most toxic constituents to produce a simple identified mixture. The mixture is then treated as such, without omitting higher risks of uncertainty due to the possible interactions not taken into account (Feron and Groten, 2002; Feron et al., 1995). However, most works are currently performed on substances in pairs (hence the term binary mixtures) which permits better understanding of the problems of combined effects (Deneer, 2000).

Two main types of models have been developed for studying "mixture ecotoxicology" (Angerville et al., 2008; Boillot and Perrodin, 2008; Emmanuel et al., 2005a; Lin et al., 2004; Mercier, 2002; Szabo, 1984; Yang, 1994): the Concentration Addition model and the Independent Action model.

The Concentration Addition (CA) model was developed by Loewe and Muischnek (1926) for a mixture of $n$ substances. Each substance acts in the toxicity of the mixture in proportion to its concentration. In other words, if a mixture contains three substances acting in the 


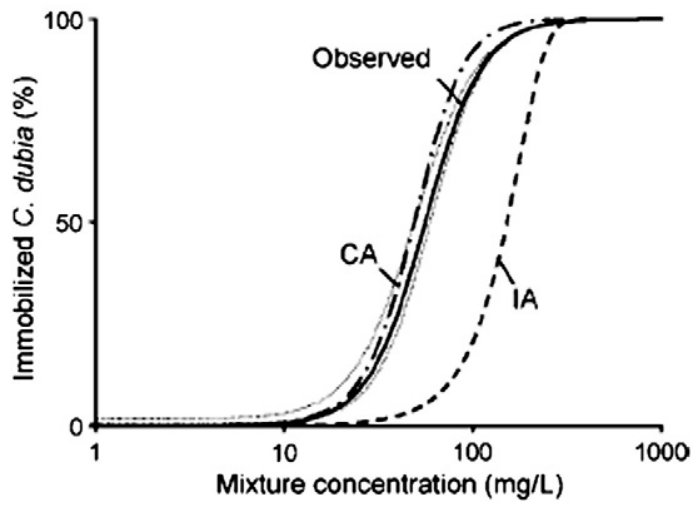

Fig. 1. Example of a dose-response curve comparing the CA and IA to experimental results for a mixture of beta-blockers and versus the immobilisation of Ceriodaphnia dubia (Fraysse and Garric, 2005).

same way and each of these substances is in a concentration equivalent to one third of its LC 50 for an organism, it can be expected that this mixture will kill half the organisms exposed (Suter, 2006). The CA is used to estimate the global response of a mixture (the entire dose-response curve) but is limited to the study of a type of effect (e.g., inhibition of respiration), for a ratio of substances that remains fixed and whose global concentration varies (Barata et al., 2006).

The CA is generally defined by the following equation:

$C E x_{\text {mix }}=\left(\sum_{i=1}^{n} \frac{p i}{C E x_{i}}\right)^{-1}$

with $n$ being the number of substances $i$ in mixture, $p_{i}$ is the proportion of substance $i$ in the mixture, $C E x_{i}$ is the concentration of substance $i$ leading to $\mathrm{x} \%$ effect and $C E x_{\text {mix }}$ is the concentration of the mixture leading to $\mathrm{x} \%$ effect (in $\mathrm{mg} / \mathrm{l}$ ).

pi can be obtained with the following equation:

$p i=\mathrm{Ci} / \mathrm{Cmix}$

with $\mathrm{C} i$ being the concentration of substance $i$ in mixture (in $\mathrm{mg} / \mathrm{l}$ ) and Cmix the total concentration of the mixture (in $\mathrm{mg} / \mathrm{l}$ ).

thus we obtain:

$C m i x=\sum C i$

Theoretically, the CA model can only be used for substances having the same action site, but most studies use it for all substances capable of giving the same toxicological response (Cleuvers, 2003; Faust et al., 2001). This model is that most used in mixture ecotoxicology (Altenburger et al., 2000; Backhaus et al., 2003; Lin et al., 2004; Vighi et al., 2003; Walter et al., 2002).

The Independent action (IA) model was developed by Bliss (1939). As with the $\mathrm{CA}$, it permits visualising the global response of a mixture (the entire dose-response curve). The IA is based on the dissimilar action of substances in mixture (Backhaus et al., 2003; Faust et al., 2001). The substances act on different sites independently. This means that the effect of a compound is not modified by the presence of another (Cleuvers, 2003). An organism will die, for example, from the effects of the substance in mixture to which it most sensitive in terms of concentration (Suter, 2006). The IA model is also limited to the study of a type of effect, for a ratio of substances remaining fixed and whose global concentration varies (Barata et al., 2006).
The effect of a mixture of $n$ substances can therefore be calculated by using the following equation:

$\mathrm{E}(\mathrm{Cmix})=E\left(C_{A}+C_{B}+C_{C}+\ldots+C n\right)=1-\prod_{i=1}^{n}(1-E(C i))$

with $C_{i}$ being the concentration of substance $i$ in mixture (in $\mathrm{mg} / \mathrm{l}$ ); $E(\mathrm{Cmix})$ and $E(\mathrm{Ci})$ are the effect if the mixture of $n$ substances and substance $i$ respectively (in \% effect).

The IA model implies that the substances that, in a given mixture, are in a concentration lower than their effect concentration do not contribute in any way to the global toxicity of the mixture (Backhaus et al., 2003; Cleuvers, 2003).

It should be noted that this model is often used in mixture ecotoxicology in unison with the Concentration Addition concept (Fig. 1), in order to determine a posteriori, the modes of action of substances in a mixture (Altenburger et al., 2000; Backhaus et al., 2003; Fraysse and Garric, 2005; Garric and Coquery, 2006; Olmstead and LeBlanc, 2005; Vighi et al., 2003).

The TU model (Toxic Unit) entails the quantitative analysis of the effects of mixtures and was introduced by Brown (1968) and Sprague (1970). It is based on the additivity of concentrations and permits estimating the deviation of the combined effects in relation to the additivity of the concentrations and a given effect value such as EC50 (EIFAC, 1980; Environnement Canada, 1999; Hermens and Leeuwangh, 1982; Warne, 2003). This model, well-known to ecotoxicologists, opens the door to the TI model. According to Yang (1994), the combined effects in a binary mixture can differ considerably as a function of the ratio of each of the constituents, and the TU and TI models make it possible to assess the combined effects of mixtures with different ratios.

The calculation of TU for substance $i$ is done by using the following equation:

$T U i=(C i / C E x i)$

$=\left(p i^{*} C_{m i x}\right) / C E x i$

with TUi being the Toxic Unit of the substance $i$; $C i\left(\mathrm{ou}_{m i x}\right)$ : concentration of substance $i$ in mixture (or ${ }_{m i x}$, of mixture) (in mg/l); CExi: concentration of substance $i$ causing $\mathrm{x} \%$ effect (in $\mathrm{mg} / \mathrm{l}$ ); pi: percentage of $i$ in the mixture.

The sum of TU of two substances makes it possible to assess the combined effects of the mixture of these two substances, as the ratios involved are dimensionless (Junghans et al., 2006; Warne and Schifko, 1999). If the sum of the TU of the constituents in the mixture is equal to 1 , it can be assumed that the effects of the mixture are of "concentration additivity" type regarding the organism under study. If the sum is less than 1, then it can be assumed that "antagonist concentration" effects will be obtained. If it is higher than 1, the effects will of "synergistic concentration" type.

By extending the TU model, Marking (1977) and Belkhadir (1979) contributed to the development of the TI model (Toxicity Index of additive joint action of toxicants in a mixture), also called "combination index" $\left(I_{c}\right)$ or "hazard index" $(\mathrm{HI})$. It permits identifying the general characteristics of interactions in a mixture of two or more compounds (Emmanuel, 2004; Yang, 1994).

The TI of a mixture of $n$ substances is calculated by using the following equation:

$T I=\sum_{i=1}^{n} T U i$

Leading to:

$\mathrm{TI}=1$ : the combined effects are of concentration additivity type

$\mathrm{TI}>1$ : the combined effects are of antagonistic concentration type

$\mathrm{TI}<1$ : the combined effects are of synergistic concentration type 
The model applies to substances with the same mode of action. Lastly, it is noteworthy that the hypothesis $\mathrm{TI}=1$ (implying the additivity of effect concentrations) is often widened. Thus EIFAC (1980) proposed extending this value from 1 to \pm 0.5 while Deneer (2000) proposed the application of a variation factor of 2, i.e. additivity exists for the TI values within the interval [0.5-2.0]. Deneer's proposal (2000) was justified by the statistical analysis of the results of 26 studies performed from 1972 to 1998, representing a total of over 200 mixtures of which 132 were different.

\subsubsection{The battery of mono-specific bioassays}

Contrary to substance-based approaches, the bioassay approach is based on the matrix of pollutants whose effects are characterised by tests on organisms. It is not therefore necessary to perform preliminary pollutant identification by physicochemical characterisation. This entails pertinent selection of the bioassays to be carried out and then applying them to determine the percentage of the matrix causing an effect on the target organisms. Derivation factors such as those of the TGD (ECB, 2003) are then used to calculate the percentage of the matrix having no effect on the target organisms.

Historically, the first laboratory tests aimed at assessing lethal effects (acute effects) and sublethal effects (chronic effects) of a given substance on organisms obtained from cultures or bred in the laboratory. More recently, these tests have been used to assess the ecotoxicity of complex liquid and solid matrixes such as effluents, wastes and polluted soils (Volatier, 2004). These assessments are carried out for different reasons: the management of waste, soils and polluted sites; the utilisation of sludges for agriculture; classifying wastes; and characterising pollution sources in framework of an ERA.

Mono-specific bioassays are performed under experimental conditions that are biotic (species, age) and abiotic (temperature, photoperiod, type of lighting, length of exposure, physicochemical composition of the environment) conditions that are controlled and often standardised. On the one hand, this allows fixing and controlling as well as possible factors known to cause a response from organisms and, on the other hand, comparing the results obtained, especially from different pollutants and between laboratories (Clément, 2006; Taub, 1989; Volatier, 2004). They fulfil criteria of repeatability, reproducibility, reliability and robustness as well as possible. There is no further need to prove the usefulness of monospecific tests for characterising substances and complex matrixes with respect to their intrinsic ecotoxicity. They have been demonstrated as essential for obtaining information on concentrations (of a substance or matrix) and lengths of exposure leading to effects on the mortality, reproduction, physiology and behaviour of an organism (Cairns, 1983). The sensitivity of each species of organism is specific. The "grail" of a bioassay universally sensitive to every pollutant has been abandoned (Cairns, 1986) and bioassays are now frequently linked to create batteries of bioassays. They therefore make it possible to perform full screening of the potential toxicity of the matrix or pollutants concerned.
During an ERA, the principle most often employed is that which states "protecting the most sensitive species means protecting all species and, by consequence, the ecosystems targeted". The scientific community therefore uses this basis to choose the most sensitive bioassay of the battery to perform an ERA. However, even when performed in battery, mono-specific assays cannot reproduce all the characteristics of an ecosystem. Indeed, only a small percentage of organisms (less than $1 \%$ ) can be kept in a laboratory and satisfy the experimental conditions required for carrying out a bioassay (for example, that of having less than $10 \%$ mortality in the control batch) (Cairns, 1983). Furthermore, these tests are not representative of the phenomena of competition, predation, changes of function within communities, energy flows or food cycles. Despite their theoretical shortcomings, monospecific bioassays have proven to be remarkably efficient for estimating responses at high levels of biological organisation (Cairns, 1983).

According to Maltby (1999), an overriding question remains: What organisms should be used? Selecting a battery of bioassays appears vital in order to characterise pertinent effects. A large number of batteries of bioassays have been proposed in the literature for different fields of study and matrixes. Mention can be made of those relating to (1) substances (Davoren and Fogarty, 2004; Kim et al., 2007; Radix et al., 2000); (2) effluents (Andrén et al., 1998; Naudin et al., 1995; Persoone et al., 2003; Ren and Frymier, 2003); (3) sediments (Davoren et al., 2005); (4) wastes (Clément et al., 1996; Isidori et al., 2003; Pandard et al., 2006; Rojícková-Padrtová et al., 1998); and (5) soils, sludges and composts (Juvonen et al., 2000; Schaefer, 2004).

Each team puts forward its own battery defined according to its own criteria. Confronted by this multitude of batteries of bioessais, the ADEME in France decided to take stock of the issue. A method for selecting biological toxicity and genotoxicity tests adapted to different scenarios was developed on the basis of studies of 177 publications (ADEME, 2005). This approach was described in an article published by Charissou et al. (2006): a battery of bioassays must be composed of at least three different species or must comprise at least three criteria of effects measured on the same species. In every case, whatever the combination of species and/or effect criteria, the battery must result in at least three biologically different responses. Regarding the choice of tests, two methods are highlighted in the literature:

- an a priori method: the choice of tests is based on predefined criteria - an a posteriori method: the choice of tests is decided on the basis of results from a wide-ranging series of samples and bioassays.

According to Charissou et al. (2006), it is necessary to formulate a battery in order to combine these two approaches. The optimal approach towards formulating a battery of bioassays can be divided into five steps (Charissou et al., 2006). Firstly, the a priori selection of tests must be in line with the goal sought in using the results, also called the scenario. The selection criteria must be ranked (structure, redundancy, ease of implementation, etc.) as a function of this finality. Table 2 shows the different selection criteria on the one hand, and the classification of

Table 2

Ranking of main characteristics for selecting a battery of bioassays in view to characterising polluted sites and soils and performing an ERA (ADEME, 2005).

\begin{tabular}{|c|c|c|}
\hline \multicolumn{2}{|l|}{$\begin{array}{l}\text { Main characteristics for selecting a battery for characterising } \\
\text { polluted sites and soils and ecosystem ERA }\end{array}$} & Importance of the characteristic \\
\hline Good cost/efficiency ratio & & Primordial \\
\hline No redundant information obtained & & Primordial \\
\hline Capacity for discrimination between the matrixes analysed & & Primordial \\
\hline \multirow{3}{*}{ Organisation of the battery } & Taking into account different trophic levels & Primordial \\
\hline & Types of toxicity and/or effect criteria & Primordial \\
\hline & Exposure pathways & Important \\
\hline \multirow{6}{*}{ Selection criteria of tests composing the battery } & Speed of response & Secondary \\
\hline & Ease of implementation & Primordial \\
\hline & Reproducibility & Primordial \\
\hline & Standardisation & Primordial \\
\hline & Sensitivity & Important \\
\hline & Ecological pertinence & Important \\
\hline
\end{tabular}


Table 3

Biological significance thresholds of effect criteria measured during certain aquatic ecotoxicity tests (ISO/DIS, 17616, 2006).

\begin{tabular}{|c|c|c|c|c|c|}
\hline Test category & Trophic level & Species & Reference & Effect criteria measured & Biological significance thresholds \\
\hline \multirow[t]{2}{*}{ Acute } & Decomposer & V. fischeri & ISO 11348 & Luminescence & $20 \%$ inhibition \\
\hline & Primary consumer & D. magna & ISO 6341 & Immobilisation & $20 \%$ inhibition \\
\hline \multirow[t]{4}{*}{ Chronic } & Producer & L. minor & ISO 20079 & Growth & $25 \%$ inhibition \\
\hline & & P. subcapitata & ISO 8692 & Growth & $25 \%$ inhibition \\
\hline & Primary consumer & C. dubia & ISO/CD 20665 & Mortality and reproduction & Mortality and reproduction: $30 \%$ inhibition \\
\hline & & B. calyciflorus & ISO/CD 20666 & Mortality and reproduction & $\begin{array}{l}\text { Mortality: } 30 \% \text { inhibition } \\
\text { Reproduction: } 25 \% \text { inhibition }\end{array}$ \\
\hline \multirow[t]{2}{*}{ Genotoxic } & Decomposer & S. typhimurium & ISO 13829 & Induction of UMC gene & Increase of induction rate by a factor of 2 \\
\hline & & & ISO 16240 & Induction or rate of mutant colonies & Increase of induction rate by a factor of 2 \\
\hline
\end{tabular}

these criteria in the framework of a scenario for characterising polluted sites and soils and carrying out an ERA on the other (ADEME, 2005). Once the battery has been decided, it is implemented in the experimental phase (Step 2). At the end of the second phase, a statistical analysis of the results (Step 3) is conducted to select the bioassays chosen during Step 1 that appear to be the most pertinent in relation to the scenario considered (Step 4). This entails an a posteriori selection. Finally, the choice of optimal battery is made by incorporating expert judgement (Step 5).

Regarding the effect values (or rather non-effect), those used most often are EC20 and NOEC (ECB, 2003; Ferrari et al., 2004; HallingSørensen, 2000; Han et al., 2006; Maltby, 1999; Steger-Hartmann et al., 1999). However, the choice of effect value regularly gives rise to controversy and the scientific community has not yet reached consensus on the subject (Chapman, 2000; Isnard et al., 2001). It entails defining the threshold percentage from which an effect considered significant occurs on the health of an ecosystem in the light of results obtained from a battery of bioassays. Nonetheless, the definition of an ecosystem in good health remains unclear. This widely debated issue not only falls within the scope of scientific investigation but also raises ethical and socioeconomic interrogations (Calow, 1992; Xu et al., 1999) for which there are no ready answers.

Furthermore, regarding the batteries of bioassays, several aspects have to be taken into account: they are unrepresentative of the natural environment and usually (though not always) more sensitive (Chapman, 2000). The use of NOEC and LOEC is often criticised since not only do these values depend on the range of concentrations and the number of replicates chosen, it is also impossible to attach a confidence interval to them (Bruijn and Van Leeuwangh, 1996; Chapman et al., 1996; Isnard et al., 2001; Jensen et al., 2001).

The advantage of CEX values is that they can be obtained from experimental results, by statistical regression methods. It is acknowledged that EC50 is the most reliable value from the statistical standpoint (Bruijn and Van Leeuwangh, 1996; Isnard et al., 2001). However, this value is very distant from the NOEC, whereas from the ethical standpoint, protecting only $50 \%$ of organisms in the aquatic environment is unimaginable. EC10 and sometimes EC05 or EC20 tend to be used more often (Pandard et al., 2000; Richards and Cole, 2006; Van Beelen et al., 2001) though their statistical significance is often subject to criticism (especially in the case of EC05). Van Beelen and Fleuren-Kemilä (1999) used EC10 in the framework of an ERA and considered them as being "more or less equivalent to NOEC". The study of 27 ecotoxicity datasets by Isnard et al. (2001) showed that EC10 and EC05 were values closest to NOEC. Conversely, these values are highly dependent on the regression model chosen and the confidence intervals linked to these values are often high.

Another question concerns the legitimacy of giving the same percentage of effect to every species. Indeed, one may ask whether it possible to consider that $5 \%$ inhibition in algae growth is equivalent to $5 \%$ mortality in fish (Bruijn and Van Leeuwangh, 1996)? A recent study performed in the framework of standard ISO/DIS 17616 (2006), answered this question by identifying modulated biological significance thresholds (between 20 and 30\% - Table 3) as a function of the type of bioassay and the effect criteria measured.

\subsubsection{The multi-specific bioassay approach}

Multi-specific bioassays are adapted to characterising the intrinsic ecotoxicity of a complex matrix, evaluating the physiological response of an organism in relation to a toxic substance, studying the interactions of different sources of stress, studying physiological acclimatisation and genetic adaptation through the development of tolerance and co-tolerance of organisms in response to a stress and, lastly, studying bioaccumulation phenomena (Cairns et al., 1996). Nonetheless, doubts have been expressed regarding their use for characterising and predicting effects at higher levels of biological organisation such as natural ecosystems (Cairns, 1983; Volatier, 2004). According to Taub (1997), even when used in battery, mono-specific bioassays cannot constitute a tool capable of predicting the effects of a toxic substance on natural ecosystems. The response of the latter cannot be predicted on the basis of several species tested in isolation in the laboratory, since the functioning of natural ecosystems depends on the processing involved at different levels of biological organisations, those of individuals, populations, communities and the ecosystem (Cairns, 1992; Clément, 2006). Pratt et al. (1987) asserted that they cannot be used alone as valid tools for predicting environmental risks, although they remain essential.

One of the key questions is therefore: Do the effects observed at the scale of an individual in the framework of mono-specific tests allow predicting the effects on populations and communities given that the latter are assessed on the basis of other criteria such as composition, structure and productivity (Cairns et al., 1996)? The fact of isolating a species eliminates the relations existing between species, and between species and the natural environment. Thus tests carried out at higher levels of biological organisation reveal characteristics that are not observed when an organism is studied in isolation (Cairns and Pratt, 1993). Lastly, compensation phenomena exist that ensure the functionality of the natural ecosystem is maintained, by allowing other species to take over from those that have been disturbed (Vasseur, 2000). The potential for organisms to adapt, generally observed during frequent and/or prolonged exposure, must also be taken into account (Volatier, 2004). Consequently, Cairns et al. (1996) noted that work at higher biological levels was necessary and complemented that done by using mono-specific bioassays.

Contrary to mono-specific tests, in situ studies allow studying the impacts of contamination on an environment by one or more toxic substance under real conditions. However, such studies lead to major experimental problems and are very expensive to perform (Clément, 2006). Multi-specific bioassays (mesocosms and microcosms) provide an intermediate working scale. They reproduce artificially closed ecosystems by introducing abiotic components and several species representative of the trophic levels of the aquatic environment simulated (Caquet et al., 1996). Thus they allow controlling certain physicochemical factors (temperature, photoperiods, $\mathrm{pH}$, oxygenation, etc.). It is noteworthy that the distinction between microcosm and mesocosm depends for the most part on the size of the systems constituted, which in turn influences the quality of the control (Caquet et al., 2000; Petersen et al., 1999). Contrary to mono-specific bioassays, tests performed at the scale of a community or an ecosystem are 
always more difficult to reproduce and are more expensive (Cairns et al., 1996). The pertinence of biodescriptors and the spatial-temporal scale chosen influence the reliability of microcosm results. Hence, according to Carpenter (1996), the use of microcosm results can lead to major errors of appreciation. As for Calow (1996), he states that the results of a multi-specific test are not necessarily more generalisable than those of mono-specific tests.

In the domain of aquatic ecotoxicology, few microcosm or mesocosm tests are performed under standardised conditions. Their design and size vary from one research team to another and are performed case by case, according to the objectives of the study being performed (Cairns and Cherry, 1993; Crossland and La Point, 1992). They can simulate lentic or lotic ecosystems, have variable volumes and more or less diverse organisms; furthermore, and the biodescriptors chosen are also very variable. Several studies have identified different types of microcosm, mesocosm and other multi-specific tests (Cairns and Cherry, 1993; Clément, 2006; Crossland and La Point, 1992; Triffault-Bouchet, 2004) and the following classification based on the volumes of systems can be proposed:

- 150 millilitre systems (Parent-Raoult et al., 2004; Volatier, 2004),

- 1 litre system (Leffler, 1981),

- 2 litre systems (Cauzzi, 2007; Clément and Cadier, 1998),

- 3 litre systems (Taub, 1989),

- 7.5 litre systems (Pratt et al., 1987),

- 100 litre systems (Cauzzi, 2007; Clément et al., 2005; TriffaultBouchet, 2004),

- 600 litre systems (Van den Brink et al., 2002),

- 180 litre "gravel" systems (Clément, 2006),

- Artificial canals (Brunet, 2000; Kreutzweiser et al., 1995; ParentRaoult et al., 2004),

- Artificial rivers (Belanger et al., 2004; Rier and Stevenson, 2006; Volatier, 2004),

- $8 \mathrm{~m}^{3}$ systems (Caquet et al., 2001),

- $12 \mathrm{~m}^{3}$ systems (Caquet et al., 1996).

\subsection{The final characterisation of risks}

According to operational constraints and the available data, several main types of method can be used (Babut and Perrodin, 2001; US EPA, 1998):

- qualitative methods characterise risk in two or three categories, for example strong/weak/average, most usually on the basis of an expert judgement (Rivière, 1998). They can be used for comparative approaches (e.g., two types of contamination),

- methods that integrate the entire pollutant/response relation permit estimating the level of risk linked to a given level of exposure. These methods are especially useful for testing several possibilities of risk reduction, or in the case of different exposure concentrations (as a function of time or geographic area) and/or effect (chronic/ acute) (Klaine et al., 1996; Solomon et al., 1996).

- the risk quotient method, however, is that most used. It is applied by calculating a Risk Factor (RF) applied to both substance-based approaches and bioassay approaches. This factor is calculated as follows:

$R F=\frac{\text { exposition value }}{\text { non }- \text { effect value }}$

Thus calculating the RF allows distinguishing cases in which environments are:

- compatible with the practises observed without exposing the target ecosystems to excessive risk levels: the risk is deemed "acceptable" when $\mathrm{RF} \leq 1$;

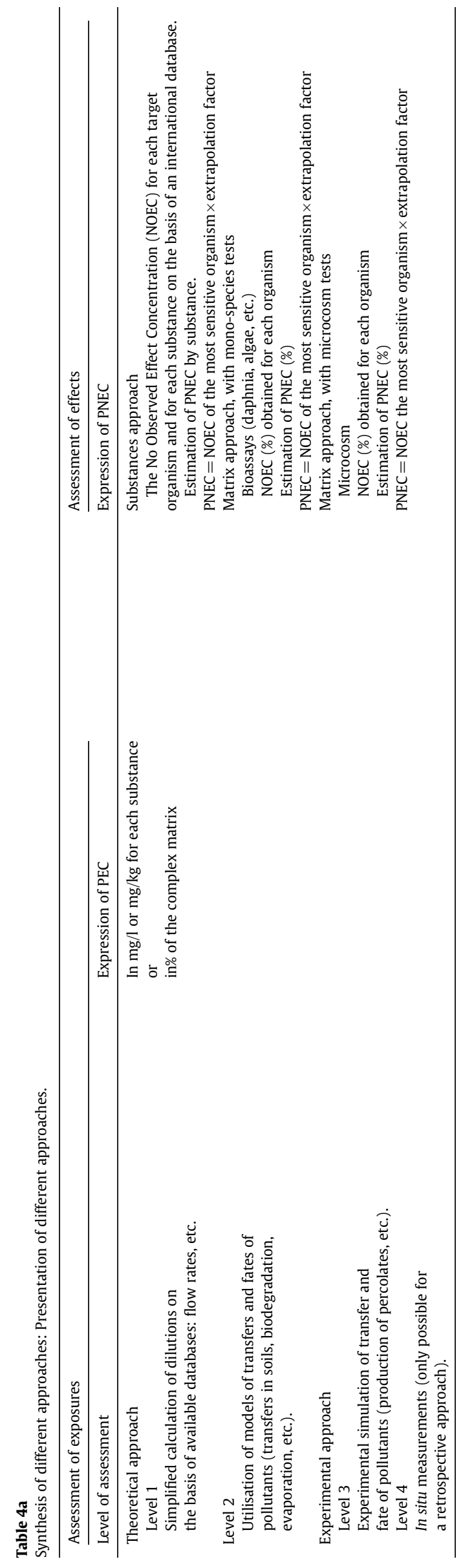




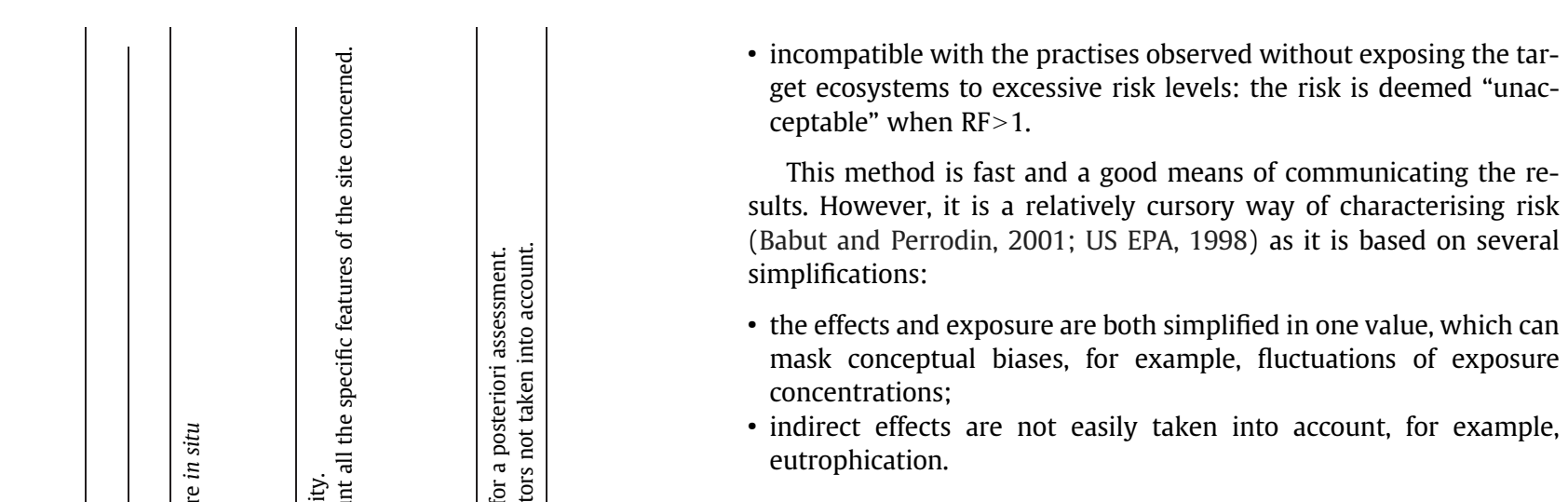

\section{Synthesis and discussion}

\subsection{Possible strategies}

When starting the study of a new scenario, it is therefore possible to choose from a wide range of approaches to characterise both exposure and effects, in view to formulating a global strategy for the ecological risk assessment to be applied. Tables $4 \mathrm{a}, 4 \mathrm{~b}, 4 \mathrm{c}$ below provides a synthesis of these approaches, and presents the advantages and disadvantages linked to each approach.

Finally, the global strategy will be defined according to these advantages and disadvantages, and also as a function of a multitude of criteria specific to the scenario to be studied (type and complexity of the pollution, type of polluted matrix, type of ecosystem potentially impacted, available budget, available competences and experimental resources, etc.).

It should be noted, nonetheless, that substance and matrix approaches are not necessarily exclusive, and that it is quite possible and relevant to implement them at the same time or one after the other. Therefore, when using the two approaches in parallel, the substance approach can be used to explain the results obtained with the matrix approach. As for their implementation in succession (the substance approach followed by the matrix approach), this is akin to an iterative approach in which the approximate results obtained quickly during the first step can then be dealt with in more detail in the second step. This may apply to all or a part of the problem dealt with.

\subsection{Discussion on taking combined effects into account}

Simultaneous studies performed on IA and CA models show globally that CA overestimates the ecotoxicity of a mixture whereas IA underestimates it (Junghans et al., 2006; Nirmalakhandan et al., 1997; Olmstead and LeBlanc, 2005). Olmstead and LeBlanc (2005) consider that the ecotoxicity of mixtures of polycyclic aromatic compounds would be better represented by IA. Regarding mixtures of pesticides, Junghans et al. (2006) evaluated a mean difference between CA and IA of 1.3 and a maximal factor between the EC50 values calculated by these two models of 2.5. The authors concluded that the estimation of effects of pesticide mixtures (independently of their modes of action) by using CA ensured protection without overestimating it. A study by Nirmalakhandan et al. (1997) confirmed this result by revealing that estimating the ecotoxicity of a mixture by CA never exceeds the experimental ecotoxicity of mixtures by an error factor of 1.4. Barata et al. (2006), stated that the responses estimated with IA would always be closer to reality for effects on organism survival. Lastly, Groten et al. (2001) demonstrated that dependence on biological response above all occurs when the substances composing the mixture play a role in enzymatic biotransformation or act on metabolism.

It appears obvious that most studies are based on concentration additivity, considered as a sufficient approach for modelling the ecotoxicity of mixtures. It generally leads to the conclusion that additivity or a deviation of additivity exists, the latter implying antagonism or 
Synthesis of different approaches: Advantages and limitations of approaches for characterising effects.

\begin{tabular}{|c|c|c|c|c|}
\hline & Substance approaches & & Matrix approaches & \\
\hline \multirow{3}{*}{ Advantages } & Substances & $\begin{array}{l}\text { Substances with combined } \\
\text { effects }\end{array}$ & Battery of mono-species bioassays & Microcosm test \\
\hline & \multicolumn{2}{|l|}{$\begin{array}{l}\text { Information on the toxicity of substances } \\
\text { available in international databases. }\end{array}$} & \multicolumn{2}{|l|}{$\begin{array}{l}\text { Interactions between substances taken into account. } \\
\text { Better account taken of the role of the environment } \\
\text { and bioavailability. }\end{array}$} \\
\hline & $\begin{array}{l}\text { The fastest and least costly } \\
\text { assessment. }\end{array}$ & $\begin{array}{l}\text { Fast assessment with account } \\
\text { taken of interactions } \\
\text { (synergy, antagonism, etc.) } \\
\text { between substances (if data } \\
\text { are available). }\end{array}$ & $\begin{array}{l}\text { Good compromise between the simplicity of tests and } \\
\text { information collected. }\end{array}$ & $\begin{array}{l}\text { Better account taken of the } \\
\text { effects of pollutants on the } \\
\text { dynamics of communities } \\
\text { (competition, } \\
\text { biomagnification, etc.). }\end{array}$ \\
\hline \multirow[t]{2}{*}{ Limitations } & \multicolumn{2}{|c|}{$\begin{array}{l}\text { Little or poor account taken of the role } \\
\text { played by the environment and bioavailability. } \\
\text { Poor choice of tracers can lead to faulty assessment. }\end{array}$} & $\begin{array}{l}\text { No information available on the individual effects of } \\
\text { the substances present. }\end{array}$ & \\
\hline & $\begin{array}{l}\text { No account taken of combined effects. } \\
\text { Least ecologically realistic method. }\end{array}$ & $\begin{array}{l}\text { Only qualitative account } \\
\text { taken of effects if the effects } \\
\text { are not additive. }\end{array}$ & $\begin{array}{l}\text { Tests with standard environments and single organisms. } \\
\text { Absence of competitors, predators, parasites, etc. }\end{array}$ & Results difficult to interpret. \\
\hline
\end{tabular}

Table 5

Recommendations for defining BCF thresholds.

\begin{tabular}{|c|c|c|}
\hline Globally harmonised system of classification and labelling of chemicals (GHS) & REACH & Stockholm convention \\
\hline UNECE (2003) & European Commission (2003) & $\operatorname{UNEP}(2006)$ \\
\hline Bioaccumulable if $\mathrm{BCF}>500$ & $\begin{array}{l}\text { Bioaccumulable if } \mathrm{BCF}>2000 \\
\text { Very Bioaccumulable if } \mathrm{BCF}>5000\end{array}$ & Bioaccumulable if $\mathrm{BCF}>5000$ \\
\hline
\end{tabular}

synergism between effect concentrations. According to Ross and Warne (1997), concentration additivity can be verified for 70 to $80 \%$ of mixtures, 10 to $15 \%$ of mixtures have antagonistic concentration effects, while the same values hold for the synergistic effects of concentrations. Jensen and Sverdrup (2002), showed that the surfactant LAS had no synergistic or antagonistic effect of concentrations on the toxicity of benzopyrene on Folsomia fimetaria. The EIFAC (1980) examined the toxicity of 76 mixtures on fish and found a TI between 0.4 and $26.87 \%$ of these mixtures fell within the interval $0.5-1.5$ with a median TI of 0.95 . A study by Deneer (2000) on more than 200 mixtures of pesticides in pairs concluded that $90 \%$ of the mixtures satisfied the principle of concentration additivity. Deviations towards increased effect were more common than towards decreased effect. Studies focusing on mixtures of substances or phytopharmaceutical compounds (acute, chronic, short and long term toxicity; mutagenesis and reproductive toxicity) have demonstrated variable combined effects (Mercier, 2002; Warne, 2003; Warne and Hawker, 1995). However, concentration additivity was encountered more frequently. A study by Warne and Hawker (1995) also showed that the higher the number of chemical substances in a mixture, the greater the probability of interactions liable to lead to concentration additivity effects.

However, there are exceptions to concentration additivity. Otitoloju (2002) found combined antagonistic type effects of concentrations for binary mixtures of metals on Tympanotonus fuscatu. Lewis (1992) reported that the combined effects of mixtures of surfactants/oil generally gave rise to synergism between concentrations. According to Suter (2006), most studies report antagonistic effects although cases of synergism exist. He added that substances exhibit different action mechanisms according to the type of exposure (acute or chronic).

\subsection{Discussion on effects rarely taken into account}

\subsubsection{Bioaccumulation in trophic chains}

Bioaccumulation is an important phenomenon in terms of its impact on ecosystems, though it is rarely taken into account in ecological risk assessments. It should be emphasised that the meaning of the term bioaccumulation differs from those of bioconcentration and biomagnification. Bioconcentration means the accumulation by an aquatic organism of substances at a concentration higher than that measured in the water in which it lives. It only takes into account contamination linked to the dissolution of a product in water. Bioaccumulation has a wider meaning that takes into account the sum of direct absorptions of a substance by respiration, the transcutaneous pathway, etc., and by feeding. On the contrary, biomagnification means the phenomenon of accumulating a substance throughout the food chain. The ingestion of contaminated foods leads to increased concentrations of the substance at every level

Table 6

Estimation of the trophic level of the waters of a lentic biotope as a function of their content in phosphorous (Ryding and Raste, 1994).

\begin{tabular}{|c|c|c|c|c|c|}
\hline Trophic category & Total phosphorous (in $\mu \mathrm{g} / \mathrm{l}$ ) & Cholorophyll $^{\mathrm{a}}$ (in $\mu \mathrm{g} / \mathrm{l}$ ) & Cholorophyll $^{\mathrm{b}}$ (in $\mu \mathrm{g} / \mathrm{l}$ ) & Transparency $^{\mathrm{a}}$ (Secchi, in $\left.\mathrm{m}\right)$ & Minimal transparency (Secchi, in m) \\
\hline Ultra-Oligotrophic & $<4$ & $<1$ & $<2.5$ & $>12$ & $>6$ \\
\hline Oligotrophic & $<10$ & $<2.5$ & $<8$ & $>6$ & $>3$ \\
\hline Mesotrophic & $10-35$ & $2.5-8$ & $8-25$ & $6-3$ & $3-1.5$ \\
\hline Eutrophic & $35-100$ & $8-25$ & $25-75$ & $3-1.5$ & $1.5-0.7$ \\
\hline Dystrophic & $>100$ & $>25$ & $>75$ & $<1.5$ & $<0.7$ \\
\hline
\end{tabular}

\footnotetext{
a Annual mean.

b Maximum annual concentration in surface waters.
} 
of the trophic network. Therefore predators are the species most exposed to these types of contaminants. The distinction between the two processes, bioconcentration/bioaccumulation and biomagnification, is important as they do not lead to the same risks. Thus certain PAHs, as opposed to PCB's, dioxins and insecticides, are bioaccumulable but do not accumulate throughout the trophic chain and so do not lead to increased risk for the predators situated at the end of the chain (Chapman, 2000).

This bioaccumulation is difficult to evaluate experimentally. At present, the most widespread means of estimating the impact of bioaccumulation on organisms is to interpret the bioconcentration factor (BCF). This parameter is relatively easy to quantify (experimentally or by modelling), and it allows appreciating the potential of a substance dissolved in water to concentrate in an aquatic organism. Some authors have proposed comparing the BCF to a threshold value (Table 5) in order to appreciate whether a substance can bioaccumulate massively in an organism and represent a risk for it (Table 5).

\subsubsection{Eutrophication}

Eutrophication designates the imbalance resulting from the excessive inflow of nutrients, in particular phosphorous and nitrogen. Since phosphorous is a generally limiting factor in natural aquatic environments (Liebig's law), the dramatic increase of eutrophication is caused by its compounds, especially phosphates. Eutrophication can be broken down into three steps:

- phosphates and nitrates are discharged into the aquatic environment; - the water enriched by them permits the rapid multiplication of aquatic plants and the proliferation of algae in particular;

- as the stock of oxygen is very limited in water, it is rapidly exhausted during periods when the respiration of organisms and the decomposition of materials produced exceeds production by photosynthesis and possible exchanges with atmospheric oxygen.

The possible development of floating plants, such as duckweed, can also prevent the passage of light and thus photosynthesis in the lower layers of water. It can also impede exchanges with the atmosphere. These phenomena cause the aquatic environment to become hypoxic and then anoxic, favouring the appearance of reducing compounds and harmful gases (mercaptans, methane, $\mathrm{NH}_{3}$ ). Such situations often favour the proliferation of toxic algae. Finally, these different phenomena can result in the death of aerobic aquatic organisms (fish, crustaceans, plants) whose decomposition and oxygen consumption amplify the imbalance.

When evaluating the risk of eutrophication, it is generally considered that the content of phosphorous in an aquatic biotope permits predicting the level of eutrophication in its water. By way of example, it is possible to determine the trophic state of a lake as a function of the phosphorous contents given in Table 6. Besides the content in phosphorous, the table also gives the content in chlorophyll and the level of water transparency which are the usual indicators of this state in limnic ecology (Table 6).

\section{Conclusion and outlook for research}

The ERA is a relatively recent tool that is attracting attention from an increasing number of professionals (managers of polluted sites, designers of transport infrastructures and urban development, managers of industrial and urban waste and effluents, government departments responsible for monitoring anthropised environments, etc.). It is a useful tool for enhancing knowledge on how the complex system studied functions, and for identifying the critical points and/or periods requiring priority action. However, it is also a tool that leaves much room for improvement and a great deal of research is necessary in a wide range of fields to strengthen its performance. The works required regarding the substance-based approach are mostly mechanistic (the behaviour mechanisms of pollutants in the environment intervening between the source and the target ecosystem, the bioavailability of substances, the mechanisms of interactions between substances, bioaccumulation mechanisms in food chains, etc.). By contrast, works relating to the matrix-based approach include, moreover, investigations on the synergy and representativeness of the batteries of bioassays to be selected for a given scenario, on the conditions of implementing bioassays on polluted matrixes (solid or liquid), and on the impact of these conditions (e.g. filtration or not of colloids before testing) on the assessment.

These works all contribute towards improving knowledge on how complex systems function with respect to the scenarios studied. These systems comprise one or more target ecosystems that are also complex systems subject to a given disturbance. Furthermore, this disturbance is seldom simple (complexity of exposure) and requires adapting not only the procedures used to implement classical ecotoxicological tools, but their configurations too. By way of example, it is rare in the field to observe ecosystems subjected to constant concentration levels, and although a range of concentrations is used, bioassays are usually performed with a constant concentration in each flask throughout the experiment conducted.

In order to characterise environmental concentrations, attention is essentially focused on optimising the interfaces between the "outputs" of these models and the "inputs" of biological models. This is true from the theoretical standpoint (linking models in cascade), from that of the compatibility of temporal scales (respective characteristic times of bio-physicochemical and ecological processes) and from spatial (meshing) practical and experimental standpoints. For example, regarding the latter, up to now no team has found a perfectly satisfactory technique for conserving simulated percolates resulting from transfer studies in view to performing ecotoxicity tests. All the methods tested in different research programmes (cold storage, freezing, X-ray sterilisation, etc.) have proved incompatible with the objectives of the study concerned (impossibility of using toxic substances to sterilise the environment, etc.), or led to a change, moreover random, in liquid samples between two types of test.

Achieving better characterisation of the exposure of organisms will depend on:

- improving toxicokinetic models (evaluating the internal dose of a toxic substance on the basis of environmental concentrations),

- improving knowledge of bioaccumulation in food chains,

- and, something that is often forgotten, progress in knowledge relating to the characterisation of organism behaviour in response to an emission of pollutants (e.g., instantaneous peaks of transient pollution due to leaks).

The matrix approach, which includes bioassays on polluted solid or liquid materials, permits partially overcoming these difficulties, especially if it is employed in exposure conditions close to reality (mesocosms, etc.).

Regarding final risk characterisation, research requirements are essentially:

- the need to calibrate and test sensitivity, then to validate ${ }^{1}$ the global risk assessment model;

- the need to improve estimating the uncertainty linked to the result, something that is always difficult.

Fundamentally interdisciplinary, future research in ERA will also require adapting the classical protocols implemented in the different disciplines concerned, especially in that of ecotoxicology, so as to

\footnotetext{
${ }^{1}$ Calibrate: define initial conditions and provide each of the parameters of the model until it provides the best possible simulation of the experimental model; Carry out a sensitivity test: identify the parameters that most influence the outputs of the model and whose acquisition is essential; Validate: verify that simulation under the new experimental conditions is good (in the laboratory and/or at intermediate level and/or in the field).
} 
make them compatible with each other, and optimise the interfaces between the different modules of the overall methodology.

\section{References}

ADEME. Évaluation de l'écocompatibilité des scénarios de stockage et de valorisation des déchets. Agence De l'Environnement et de la Maîtrise de l'Énergie, Angers; 2002. p. 148

ADEME. Développement d'une méthode de sélection des tests biologiques de toxicité et de génotoxicité adaptée à différents scénarii. Programme de recherche le l'Agence De l'Environnement et de la Maîtrise de l'Énergie; 2005.

Altenburger R, Bodeker W, Faust M, Grimme LH. Evaluation of the isobologram method for the assessment of mixtures of chemicals. Combination effect studies with pesticides in algal biotests. Ecotox Environ Safe 1990;20:98-114.

Altenburger R, Backhaus T, Boedeker W, Faust M, Scholze M, Grimme LH. Predictability of the toxicity of multiple chemical mixtures to Vibrio fischeri: mixtures composed of similarly acting chemicals. Environ Toxicol Chem 2000;19:2341-7.

Andrén C, Eklund B, Gravenfors E, Kukulska Z, Tarkpea M. A multivariate biological and chemical characterization of industrial effluents connected to municipal sewage treatment plants. Environ Toxicol Chem 1998;17:228-33.

Angerville R, Emmanuel E, Perrodin Y. Toxicity of binary mixtures of heavy metals against the freshwater algae Pseudokirchnerielia subcapitata. Toxicol. Lett. Elsevier Ireland Ltd.; 2008. p. S178.

Babut M, Perrodin Y. Évaluation écotoxicologique de matériaux de dragage - (1) présentation et justification de la démarche [en ligne]. CETMEF, Cemagref, ENTPE, VNF, Centre d'Etudes Techniques Maritimes et Fluviales; 2001. p. 47.

Backhaus T, Faust M, Junghans M, Meyer W, Scholze M, Horst Grimme L, et al. The BEAM-project: prediction and assessment of mixture toxicities in the aquatic environment. Cont Shelf Res 2003;23:1757-69.

Bai M, Elswortth D, Inyang HI, ROegiers J-C. Modeling contaminant migration with linear sorption in strongly heterogeneous media. J Environ Eng 1997;123:1116-25.

Barata C, Baird DJ, Nogueira AJA, Soares AMVM, Riva MC. Toxicity of binary mixtures of metals and pyrethroid insecticides to Daphnia magna Straus. Implications for multi-substance risks assessment. Aquat Toxicol 2006;78:1-14.

Belanger SE, Lee DM, Bowling JW, LeBlanc EM. Responses of periphyton and invertebrates to a tetradecyl-pentadecyl sulfate mixture in stream mesocosms. Environ Toxicol Chem 2004;23:2202-13.

Belkhadir, E.M. Étude sur l'écotoxicologie des hydrocarbures aromatiques légers en milieu dulçaquicole. Mémoire de thèse. Université de Metz, Metz, 1979, pp. 204.

Bermond M. Évaluation des risques écotoxicologiques : fondements théoriques et mise en application en France. Synthèse technique. École Nationale du Génie Rural, des Eaux et des Forêts. Montpellier: Office International de l'Eau; 2002. p. 16

Blanchard, C. Caractérisation de la mobilisation potentielle des poluants inorganiques dans les sols pollués. Thèse spécialité Siences et techniques du déchet. INSA de Lyon, Lyon, 2000, pp. 241.

Bliss CI. The toxicity of poisons applied jointly. Ann Appl Biol 1939;26:585-615.

Boillot C, Perrodin Y. Joint-action ecotoxicity of binary mixtures of glutaraldehyde and surfactants used in hospital: use of TI model and isoblogram representation. Ecotox Environ Safe 2008;71:252-9.

Boillot C, Emmanuel E, Perrodin Y. Étude des effets combinés du glutaraldéhyde et des surfactants contenus dans les effluents hospitaliers vis-à-vis de Daphnia magna. Déchets Sci Tech 2006;42:22-8.

Boillot C, Bazin C, Tissot-Guerraz F, Droguet J, Perraud M, Cetre JC, et al. Daily physicochemical, microbiological and ecotoxicological fluctuations of a hospital effluent according to technical and care activities. Sci Total Environ 2008;403:113-29.

Brown VM. The calculation of the acute toxicity of mixtures of poisons to rainbow trout. Water Res 1968;2:723-33.

Bruijn JHM, Van Leeuwangh CJ. Chapitre 1: no-effect concentration in environmental policy. In: Kooijman SALM, Bedaux JMM, editors. The Analyse of Aquatic Toxicity Data. Amsterdam: VU University Press; 1996. p. 1-7.

Brunet C. Effets interactifs d'une forte charge en éléments nutritifs et de la vitesse du courant sur la communauté périphytique : étude en canaux artificiels. Mémoire de Thèse - Université Claude Bernard, Lyon 1 ENTPE, LSE - Spécialité Analyse et modélisation des systèmes biologiques, Vaux-en-Velin; 2000. p. 186.

Cairns Jr J. Are single species toxicity tests alone adequate for estimating environmental hazard? Hydrobiologia 1983;100:47-57.

Cairns Jr J. The myth of the most sensitive species. Bioscience 1986;36:670-1.

Cairns Jr J, Mc Cormick PV, Belanger SE. Ecotoxicological testing: small is reliable. J Environ Pathol Toxicol Oncol 1992;11:247-63.

Cairns Jr J, Cherry DS. 7: freshwater multi-species test systems. In: Calow P, editor. Handbook of Ecotoxicology, 1. Oxford: Blackwell Scientific Publications; 1993. p. 101-16.

Cairns Jr J, Pratt JR. Trends in ecotoxicology. Proceedings of the 2nd European Conference on Ecotoxicology, 134. Sci Total Environ; 1993. p. 7-22.

Cairns Jr J, Bidwell JR, Arnegard ME. Toxicity testing with communities: microcosms, mesocosms, and whole-system manipulations. Rev Environ Contam Toxicol 1996;147:45-69.

Calow P. Can ecosystems be healthy? Critical consideration of concepts. J Aquat Ecosyst Health 1992;1:1-5.

Calow P. 1: general principles and overviews. In: Calow P, editor. Handbook of Ecotoxicology, Vol. 1. Oxford: Blackwell Scientific Publications; 1993. p. 1-5.

Calow P. Variability: noise or information in ecotoxicology? Environ Toxicol Pharmacol 1996;2:121-3.

Caquet T, Lagadic L, Jonot O, Baturo W, Kilanda M, Simon P, et al. Outdoor experimental ponds (mesocosms) designed for long-term ecotoxicological studies in aquatic environment. Ecotox Environ Safe 1996;34:25-133.
Caquet T, Lagadic L, Sheffield SR. Mesocosms in ecotoxicology (1): outdoor aquatic systems environment. Rev Environ Contam Toxicol 2000;165:1-38.

Caquet T, Lagadic L, Monod G, Lacaze J-C, Couté A. Variability of physicochemical and biological parameters between replicated outdoor freshwater lentic mesocosms. Ecotoxicology 2001;10:51-66.

Carpenter SR. Microcosm experiments have limited relevance for community and ecosystem ecology. Ecology 1996;77:677-80.

Cauzzi, N. Évaluation de l'éco-compatibilité de sédiments contaminés, traités et non traités par un procédé physico-chimique, dans le cadre d'un scénario de dépôt en gravière - Étude en microcosmes aquatiques. PhD - INSA de Lyon - Spécialité Sciences et Techniques du Déchet au LSE/ENTPE. INSA de Lyon, Villeurbanne (France), 2007, pp. 341.

CEAEQ. Procédure d'évaluation des risques écotoxicologiques pour la réhabilitation des terrains contaminés. Centre d'Expertise en Analyse Environnementale du Québec, Québec; 1998. p. 139.

CEN/TS 14405. Characterization of waste. Leaching Behaviour TestsUp-flow Percolation Test (Under Specified Conditions); 2004.

CETMEF. Évaluation écotoxicologique de sédiments contaminés ou de matériaux de dragage. Direction de la Recherche et des Affaires Scientifiques et Techniques du Ministère de l'Equipement des Transports et du Logement et par Voies navigables de France, Centre d'Etudes Techniques Maritimes et Fluviales; 2001. p. 12.

Chapman PM. Whole effluent toxicity testing - usefulness, level of protection, and risk assessment. Environ Toxicol Chem 2000;19:3-13.

Chapman PM, Cardwell RS, Chapman PF. A warning: NOECs are inappropriate for regulatory use. Environ Toxicol Chem 1996:15.

Charissou AM, Jourdain MJ, Pandard P, Poulsen V, Devillers J, Férard JF, et al. Démarche optimale de sélection de batterie de bioessais pour l'évaluation écotoxicologique des milieux complexes. Synthèse bibliographique. Tech Sci Meth 2006;5:101-10.

Clément B. Apports des essais en microcosmes aquatiques lentiques de laboratoire à l'évaluation écotoxicologique des polluants. Mémoire d'HDR - INSA de Lyon et Université Lyon1, Spécialité Biologie et Biochimie Appliquées au LSE de l'ENTPE, Vaulx-en-Velin; 2006. p. 277.

Clément B, Cadier C. Development of a new laboratory freshwater/sediment microcosm test. Ecotoxicology 1998;7:279-90.

Clément B, Persoone G, Colin J, Du-Delepierre A. Estimation of the hazard of landfills through toxicity testing of leachates. I. Determination of leachate toxicity with a battery of acute tests. Chemosphere 1996;33:2303-20.

Clément B, Cauzzi N, Godde M, Crozet K, Chevron N. Pyrene toxicity to aquatic pelagic and benthic organisms in single-species and microcosm tests. Polycycl Aromat Comp 2005;25:271-98.

Cleuvers M. Aquatic ecotoxicity of pharmaceuticals including the assessment of combination effects. Toxicol Lett 2003;142:185-94.

Corapcioglu M, Jiang S. Colloid facilitated groundwater contaminant transport. Water Resour Res 1993;29:2215-26.

Crossland NO, La Point TW. The design of mesocosm experiment. Environ Toxicol Chem $1992 ; 11: 1-4$

Davoren M, Fogarty AM. A test battery for the ecotoxicological evaluation of the agrichemical environ. Ecotox Environ Safe 2004;59:116-22.

Davoren M, Ni Shúilleabháin S, O'Halloran J, Hartl MGJ, Sheehan D, O'Brien NM, et al. A test battery approach for the ecotoxicological evaluation of estuarine sediments. Ecotoxicology 2005;14:741-55.

De Smedt F, Wierenga PJ. A generalized solution for solute flow in soils with mobile and immobile water. Water Resour Res 1979;15:1137-41.

Deneer JW. Toxicity of mixtures of pesticides in aquatic systems. Pest Manag Sc 2000;56:516-20.

Donguy G, Perrodin Y. Guide méthodologique d'évaluation des risques écologiques liés aux aménagements urbains et aux infrastructures de transport. Vaulx en Velin: LSE-ENTPE; 2006. p. 65.

Donguy G, Perrodin Y. Évaluation des risques écologiques dans le domaine des sites pollués. Définitions, concepts et usages des outils existantsADEME, ENTPE-LSE; 2007. p. 52.

ECB. Technical Guidance Document (TGD) in support of Commission Directive 93/67/EEC on Risk Assessment for new notified substances, Commission Regulation (EC) No 1488/94 on Risk Assessment for existing substances and Directive 98/8/EC of the European Parliament and of the Council concerning the placing of biocidal products on the market. European Chemical Bureau, Ispra (Italy); 2003. p. 1044.

EIFAC. Report on combined effects on freshwater fish and other aquatic life of mixtures of toxicants in water. Food and Agriculture Organization of the United Nations, Rome; 1980.

Emmanuel E. Évaluation des risques sanitaires et écotoxicologiques liés aux effluents hospitaliers. Thèse Spécialité Sciences et Techniques du Déchet. INSA de Lyon et LSE-ENTPE, Villeurbanne et Vaulx en Velin, 2004, pp. 259.

Emmanuel E, Perrodin Y, Blanchard JM, Keck G, Vermande P. Approche méthodologique de l'évaluation des risques écotoxicologiques des effluents hospitaliers vis-à-vis de la STEP locale et de l'écosystème aquatique récepteur, 35. Déchets - Sciences et Techniques - La Revue Francophone d'Ecologie Industrielle; 2004. p. 18-27.

Emmanuel E, Hanna K, Bazin C, Keck G, Clement B, Perrodin Y. Fate of glutaraldehyde in hospital wastewater and combined effects of glutaraldehyde and surfactants on aquatic organisms. Environ Int 2005a;31:399-406.

Emmanuel E, Perrodin Y, Keck G, Blanchard JM, Vermande P. Ecotoxicological risk assessment of hospital wastewater: a proposed framework for raw effluents discharging into urban sewer network. J Hazard Mater 2005b;117:1-11.

EN 12457. Characterization of waste - leaching. Compliance test for Leaching of Granular Waste Materials and Sludges; 2003.

Environment Agency of United Kingdoms. Ecological risk assessment. A Public Consultation on A Framework and Methods for Assessing Harm to Ecosystems from 
Contaminants Soil. Bristol (UK): Environment Agency of United Kingdoms; 2003. p. 104.

Environnement Canada. Guide des essais écotoxicologiques employant une seule espèce et de l'interprétation des résultats. Section de l'élaboration et de l'application des méthodes, centre de technologie environnementale; 1999. p. 209.

European Commission, Technical Guidance Document in support of Commission Directive 93/67/EEC on Risk assessment for new notified substances and Commission Regulation (EC). No 1488/94 on Risk assessment for existing substances and Commission Directive (EC) 98/8 on Biocides, second ed. European Commission, Vol. Part 1, 2 and 3, Luxembourg; 2003, 760p.

Faust M, Altenburger R, Backhaus T, Blanck H, Boedeker W, Gramatica P, et al. Predicting the joint algal toxicity of multi-component s-triazine mixtures at low-effect concentrations of individual toxicants. Aquat Toxicol 2001;56:13-32.

Feron VJ, Groten JP. Toxicological evaluation of chemical mixtures. Food Chem Toxicol 2002;40:825-39.

Feron VJ, Groten JP, Tonker D. Toxicological of chemical mixtures: challenges for today and the future. Toxicology 1995;105:415-27.

Ferrari B, Mons R, Vollat B, Fraysse B, Paxeus N, Lo Giudice R, et al. Environmental risk assessment of six human pharmaceuticals: are the current environmental risk assessment procedures sufficient for the protection of the aquatic environment? Environ Toxicol Chem 2004;23:1344-54.

Forbes VE, Calow P. Extrapolation in ecological risk assessment: balancing pragmatism and precaution in chemical controls legislation. Bioscience 2002a;52:249-57.

Forbes VE, Calow P. Population growth rate as a basis for ecological risk assessment of toxic chemicals. Philos Trans R Soc Lond B Biol Sci 2002b;357: 1299-306.

Fraysse B, Garric J. Prediction and experimental validation of acute toxicity of betablockers in Ceriodaphnia dubia. Environ Toxicol Chem 2005;24:2470-6.

Garric, J., Coquery, M. Caractéristiques des substances médicamentauses et contamination des milieux récepteurs. In: GRAIE, editor. Eau et santé. Eau pluviales et Assainissement:nouvelles préoccupations sanitaires, Lyon-Villeurbanne, 2006, pp. 75-85.

Gaudet J-P, Jegat H, Vachaud G, Wierenga PJ. Solute transfer, with exchange between mobile and stagnant water, through unsaturated sand. Soil Sci Am J 1977;41: 665-71.

Greco WR, Bravo G, Parsons JC. The search for synergy: a critical review from a response surface perspective. Pharmacol Rev 1995;47:331-85.

Grolimund D, Borkovec M. Release and transport of colloidal particles in natural porous media: 1. Modelling. Water Resour Res 2001;37:559-70.

Groten JP, Feron VJ, Sühnel J. Toxicology of simple and complex mixtures. Trends Pharmacol Sci 2001;22:316-22.

Hahn $\mathrm{mH}$, Abadzic D, O'mellia C. Colloid transport in porous media under unfavorable chemical conditions II: experimental assessment and implications. Environ Sci Technol 2004;38:210-20.

Halling-Sørensen B, Holten Lutzhoft H-C, Andersen HR, Ingerslev F. Environmental risk assessment of antibiotics: comparison of mecillinam, trimethoprim and ciprofloxacin. J Antimicrobial Chemother 2000;46:53-8.

Han GH, Hur HG, Kim SD. Ecotoxicological risk of pharmaceuticals from wastewater treatment plants in Korea: occurrence and toxicity to Daphnia magna. Environ Toxicol Chem 2006;25:265-71.

Hayet A. Variabilité des méthodologies d'évaluation des risques écologiques : conséquences et perspectives d'améliorations. Mémoire de master recherche en ingénierie de la santé. Mention Santé - EnvironnementInstitut Lillois d'Ingénierie de la Santé, Université de Lille; 2006. p. 95.

Hermens JLM, Leeuwangh P. Joint toxicity of chemicals to Guppy (Poecilia reticulata). Ecotox Environ Safe 1982;6:302-10.

Hinz C, Sinke AJC, Martins JM, Fluhler H. Transport of organic pollutants in unsaturated soil: preface and overview. J Contam Hydrol 1998;33:1-3.

INERIS. Catalogue des concentrations prévisibles sans effet dans l'environnement aquatique (PNEC aqua) des substances chimiques existantes ayant fait l'objet d'une évaluation dans le cadre du règlement CEE n $793 / 93$ et du programme OCDE. INERIS, Verneuil-en-Halatte, Paris; 1999.

INERIS. Portail substances chimiques - base de donnees environnementales. F. Le Golf; 2006.

Isidori M, Lavorgna M, Nardelli A, Parrella A. Toxicity identification evaluation of leachates from municipal solid waste landfills: a multispecies approach. Chemosphere 2003;52:85-94

Isnard P, Flammarion P, Roman G, Babut M, Bastien P, Bintein S, et al. Statistical analysis of regulatory ecotoxicity tests. Chemosphere 2001;45:659-69.

ISO 18772 . Soil quality - leaching procedures for subsequent chemical and ecotoxicological testing of soil and soil materials; 2007.

ISO/DIS 17616. Qualité du sol - Lignes directrices pour l'évaluation des essais appliqués dans le domaine de la caractérisation écotoxicologique des sols et des matériaux du sol; 2006.

ISO/TS 21268-1 21268-2 21268-3. Soil quality - leaching procedures for subsequent chemical and ecotoxicological testing of soil and soil materials; 2007.

Jauzein M, Jourdain M-J, Bispo A, Savanne D. Écotoxicité des sols et des déchets: extractions des polluants. ADEME, Paris; 1999.

Jensen J, Sverdrup LE. Joint toxicity of linear alkylbenzene sulfonates and pyrene on Folsomia fimetaria. Ecotox Environ Safe 2002;52:75-81.

Jensen J, Lokke H, Holmstrup M, Krogh PH, Elsgaard L. Effects and risk assessment of linear alkylbenzenz sulfonates in agricultural soil. 5. Probabilistic risk assessmen of linear alkylbenzenz sulfonates in sludge-amended soils. Environ Toxicol Chem 2001;20:1690-7.

Junghans M, Backhaus T, Faust M, Scholze M, Grimme LH. Application and validation of approaches for the predictive hazard assessment of realistic pesticide mixtures. Aquat Toxicol 2006;76:93-110.
Jury WA, Roth K. Transfer functions and solute movement through soil. Theory and applications. Birkhauser Verlag; 1990.

Juvonen R, Martikainen E, Schultz E, Joutti A, Ahtiainen J, Lehtokari M. A battery of toxicity tests as indicators of decontamination in composting oily waste. Ecotox Environ Safe 2000;47:156-66.

Kim Y, Choi K, Jung J, Park S, Kim P-G, Park J. Aquatic toxicity of acetaminophen, carbamazepine, cimetidine, diltiazem and six major sulfonamides, and their potential ecological risks in Korea. Environ Int 2007;33:370-5.

Klaine SJ, Cobb GP, Dickerson RL, Dixon KR, Kendall RJ, Smith EE, et al. An ecological risk assessment for the use of the biocide, dibromonitrilopropionamide (DBNPA), in industrial cooling systems. Environ Toxicol Chem 1996;15:21-30.

Köhne JM, Köhne S, Šimůnek J. A review of model applications for structured soils: a) Water flow and tracer transport. J Contam Hydrol 2009;104:16.

Korte NE, Skopp J, Fuller WH, Niebla EE, Alesii BA. Trace element movement in soils: influence of soil physical and chemical properties. Soil Sci 1976;122:350-9.

Kreutzweiser DP, Capell SS, Sousa BC. Hexazinone effects on stream periphyton and invertebrate communities. Environ Toxicol Chem 1995;14:1521-7.

Leffler JW. Aquatic microcosms and stress criteria forassessing environmental impact of organic chemicals. US EPA. Washington: Office of pesticides and Toxic substances; 1981. p. 50.

Lewis MA. The effects of mixtures and other environmental modifying factors on the toxicities of surfactants to freshwater and marine life. Water Res 1992;26: 1013-23.

Lin Z, Du J, Yin K. Mechanism of concentration addition toxicity: they are different for nonpolar narcotic chemicals, polar narcotic chemicals and reactive chemicals. Chemosphere 2004;54:1691-701.

Loewe S, Muischnek H. Über Kombinationswirkungen. 1. Mitteilung: Hilfsmittel der Fragestellung. Naunyn Schmiedebergs. Arch Exp Pathol Pharmakol 1926;114:313-26.

Ma L, Selim HM. Transport of a nonreactive solute in soils: a two-flow domain approach. Soil Sci 1995;159:1-11.

Ma L, Selim HM. Solute transport in soils under condition of variable flow velocities. Water Resour Res 1996;32:3277-83.

Maltby L. Studying stress: the importance of organism-level responses. Ecol Appl 1999;9:431-40.

Marking LL. Method for assessing additive toxicity of chemical mixtures. Aquat Toxicol Hazard Eval 1977;634:99-108.

Massoudieh A, Ginn TR. Modeling colloid-enhanced contaminant transport in stormwater infiltration basin best management practices. Vadose Zone J 2008;7:1215-22.

Mc Gechan M, Lewis D. Transport of particulate and colloid sorbed contaminants through soil, part 1: general principles. Biosyst Eng 2002;83:255-73.

Mercier T. Avis de la Commission d'Étude de la Toxicité concernant les mélanges de produits phytopharmaceutiques. Réponses aux questions faisant l'objet d'une saisine de la Commission par la Direction Générale de l'Alimentation. Versailles: INRA; 2002. p. 29.

Miller CW, Benson LV. Simulation of solute transport in a chemically reactive heterogeneous system: model development and application. Water Resour Res 1983;19:381-91.

Mills W, Liu S, Fong F. Literature review and model (COMET) for colloid/metals transport in porous media. Ground Water 1991;29:199-208.

Naudin S, Garric J, Vindimian E, Bray M, Migeon B, Vollat B, et al. Influence of the sample preservation mode to assess the chronic toxicity of an industrial effluent. Ecotox Environ Safe 1995;30:54-62.

Neville CJ, Ibaraki M, Sudicky EA. Solute transport with multiprocess nonequilibrium: a semi-analytical solution approach. J Contam Hydrol 2000;44:141-59.

Nielsen DR, Van Genuchten MT, Biggar JW. Water flow and solute transport processes in the unsaturated zone. Water Resour Res 1986;22:895-1085.

Nirmalakhandan N, Xu S, Trevizo C, Brennan R, Peace J. Additivity in microbial toxicity of nonuniform mixtures of organic chemicals. Ecotox Environ Safe 1997;37:97-102.

Olmstead AW, LeBlanc GA. Joint action of polycyclic aromatic hydrocarbons: predictive modeling of sublethal toxicity. Aquat Toxicol 2005;75:253-62.

Otitoloju AA. Evaluation of the joint-action toxicity of binary mixtures of heavy metals against the mangrove periwinkle Tympanotonus fuscatus var radula (L.). Ecotox Environ Safe 2002;53:404-15.

Pandard P, Poulsen V, Magaud H, Lhenry MC, Thybaud E. Ecotoxicological caracterisation of water (Poster). 3rd SETAC World Congress, Bringhton; 2000.

Pandard P, Devillers J, Charissou A-M, Poulsen V, Jourdain M-J, Férard J-F, et al. Selecting a battery of bioassays for ecotoxicological characterization of wastes. Sci Total Environ 2006;363:114-25.

Parent-Raoult, C. Étude en systèmes artificiels de laboratoire des effets de Rejets Urbains de Temps de Pluie sur les communautés périphytiques : influence de facteurs d'exposition. Thèse Université Claude Bernard, Lyon 1 - Analyse et Modélisation des Systèmes Biologiques, Spécialité : Ecosystèmes, Evolution, Modélisation, Microbiologie, 2004, pp. 240.

Parker JC, Van Genuchten MT. Flux-averaged and volume-averaged concentrations in continuum approaches to solute transport. Water Resour Res 1984;20:866-72.

Perrodin Y, Grelier-Volatier L, Barna R, Gobbey A. Assessment of the ecocompatibility of waste disposal or waste use scenarios: towards the elaboration and implementation of a comprehensive methodology. Waste Manag Ser 2000;1:504-12.

Perrodin Y, Babut M, Bedell J-P, Bray M, Clément B, Delolme C, et al. Approche méthodologique de l'évaluation des risques écotoxicologiques liés à la mise en dépôt sur sol de sédiments de dragage. Déchets Sci Tech 2004;34:4-14.

Persoone G, Marsalek B, Blinova I, Torokne A, Zarina D, Manusadzianas L, et al. A practical and user-friendly toxicity classification system with microbiotests for natural waters and wastewaters. Environ Toxicol 2003;18:395-402.

Petersen JE, Cornwell JC, Kemp WM. Implicit scaling in the design of experimentl aquatic ecosystems. OIKOS 1999;85:3-18.

Plackett RL, Hewlett PS. Quantal reponses to mixtures of poisons. J R Stat Soc 1952;14:141. 
Pratt JR, Niederlehner BR, Bowers N, Cairns Jr J. Prediction of permissible concentrations of copper from microcosm toxicity tests, 2. Toxicity Assessment: An International Quaterly; 1987. p. 417-36.

Radix P, Léonard M, Papantoniou C, Roman G, Saouter E, Gallotti-Schmitt S, et al. Comparison of four chronic toxicity tests using algae, bacteria, and invertebrates assessed with sixteen chemicals. Ecotox Environ Safe 2000;47:186-94.

RECORD. Évaluation et acceptabilité des risques environnementaux. Méthodes d'évaluation, analyse comparative; Etude sociologiques des représentations des risques, synthèse bibliographique; 2006. p. 227.

Ren S, Frymier PD. Use of multidimensional scaling in the selection of wastewater toxicity test battery components. Water Res 2003;37:1655-61.

Richards SM, Cole ÆSE. A toxicity and hazard assessment of fourteen pharmaceuticals to Xenopus laevis larvae. Ecotoxicology 2006:15.

Rier ST, Stevenson RJ. Response of periphytic algae to gradients in nitrogen and phosphorus in streamside mesocosms. Hydrobiologia 2006;561:131-47.

Rivière JL. Évaluation du risque écologique des sols pollués. Lavoisier, Paris; 1998.

Rojícková-Padrtová R, MarIsálek B, Holoubek I. Evaluation of alternative and standard toxicity assays for screening of environmental samples: selection of an optimal test battery. Chemosphere 1998;37:495-507.

Ross $\mathrm{H}$, Warne M. Most chemical mixtures have additive aquatic toxicity. Proceedings of the Third Annual Conference of the Australasian Society for Ecotoxicology, Brisbane; 1997. p. 21.

Ryding SO, Raste W. Le contrôle de l'eutrophisation des lacs et réservoirs. Sciences de l'Environnement; 1994.

Sardin M, Schweich D, Leij FJ, Van Genuchten MT. Modeling the nonequilibrium transport of linearly interacting solutes in porous media: a review. Water Resour Res 1991;27:2287-307.

Schaefer M. Assessing 2,4,6-trinitrotoluene (TNT)-contaminated soil using three different earthworm test methods. Ecotox Environ Safe 2004:57:74-80.

Selim HM, Ma L, Zhu H. Predicting solute transport in soils: second-order two site models. Soil Sci Soc Am J 1999;63:768-77.

Simon D, Helliwell S, Robards K. Pesticide toxicity endpoints in aquatic ecosytems. J Aquat Ecosyst Stress Recov 1998;6:159-77.

Solomon KR, Baker DB, Richards RP, Dixon KR, Klaine SJ, La Point TW, et al. Ecological risk assessment of atrazine in North American surface waters. Environ Toxicol Chem 1996;15:31-76.

Spencer WF, Farmer WJ, Jury WA. Review: behavior of organic chemicals at soil, air, water interfaces as related to predicting the transport and volatilization of organic pollutants. Environ Toxicol Chem 1982;1:17-26.

Sprague JB. Measurement of pollutant toxicity to fish. II. Utilizing and applying bioassay results. Water Res 1970;4:3-32.

Steger-Hartmann T, Lange R, Schweinfurth H. Environmental risk assessment for the widely used iodinated X-ray contrast agent iopromide (ultravist). Ecotox Environ Safe 1999;42:274-81.

Suter GW. Environmental risk assessment. Chelsea: Lewis Publishers; 1993.

Suter II GW. Ecological risk assessment. CRC Press, Boca Raton, Florida; 2006.

Szabo C. Toxicité aiguë et interactions de certains pesticides (lindane - pentachlorophénol) utilisé dans le traitement du bois. Étude sur Brachydanio rerio. Mémoire de DEA en Écologie Fondamentale et appliquée des Eaux Continentales. Université Claude Bernard Lyon I/ École nationale vétérinaire de Lyon, Lyon; 1984. p. 53.

Taub FB. Standardized aquatic microcosm. In: Boudou A, Rybeyre F, editors. Development and Testing. Aquatic Ecotoxicology: Fundamentals, Concepts and Methodologies.Boca Raton, Florida: CRC Press; 1989. p. 47-91.

Taub FB. Unique information contributed by multispecies systems: examples from the standardized aquatic microcosm. Ecol Appl 1997;7:1103-10.
Travis CC, Etnier EL. A survey of sorption relationships for reactive solutes in soil. J Environ Qual 1981;10:8-17.

Trépanier JP. Terrasys. Varennes (Quebec): SANEXEN; 2005.

Triffault-Bouchet, G. Effets sur les écosystèmes aquatiques lentiques des émissions de polluants provenant de différents modes de valorisation/élimination de déchets application à des mâchefers d'UIOM et à des boues de dragage de canaux. Thèse Spécialité : Biologie et Biochimie Appliquées au LSE de l'ENTPE. Université de Savoie, Chambéry, Vaux en Velin, 2004, pp. 309.

UNECE, Globally Harmonized system for classification and labeling of chemicals. United Nations Economic Commission for Europe; 2003.

UNEP, Stockholm convention on persistent organic pollutants (POPs). United Nations Environmental Program; 2006.

US EPA. Guidelines for Ecological Risk Assessment. Washington: United States Environmental Protection Agency; 1998. p. 188.

Van Beelen P, Fleuren-Kemilä AK. A comparison between toxicity tests using single species aand microbial process. Chemosphere 1999;38:3277-90.

Van Beelen P, Fleuren-Kemilä AK, Aldenberg T. The relation between extrapolated risk, expressed as potentially affected fraction, and community effects, expressed as pollution-induced community tolerance. Environ Toxicol Chem 2001;20: 1133-40.

Van den Brink PJ, Hartgers EM, Gylstra R, Bransen F, Brock TCM. Effects of a mixture of two insecticides in freshwater microcosms: II. Responses of plankton and ecological risk assessment. Ecotoxicology 2002:11.

Vasseur P. Modèles d'effets. Les cahiers des Clubs CRIN, MATE, Modélisation en écotoxicologie, Paris; 2000. p. 95-8.

Vighi M, Finizio A, Altenburger R, Walter $\mathrm{H}$, Arrhenius A, Blanck $\mathrm{H}$, et al. Water quality objectives for mixtures of toxic chemicals: problems and perspectives. Ecotox Environ Safe 2003;54:139-50.

Volatier L. Réponse d'une communauté périphytique à un effluent complexe : études en bio-essais et canaux artificiels. Thèse - Spécialité Sciences et Techniques du Déchet au LSE de l'ENTPE. INSA de Lyon, Vaux en Velin, 2004, pp. 303.

Walter $\mathrm{H}$, Consolaro F, Gramatica P. Mixture toxicity of priority pollutants at No Observed Effect Concentration (NOECs). Ecotoxicology 2002;11:299-310.

Warne MSJ. A review of the ecotoxicity of mixtures, approaches to, and recommendation for, their management. In: Langley A, Gilbey M, Kennedy B, editors. Fifth National Workshop on the Assessment of Site Contamination. Adelaide: EPHC-NEPC - en Health; 2003. p. 253-76.

Warne MSJ, Hawker DW. The number of components in a mixture determines whether synergistic and antagonistic or additive toxicity predominate: the funnel hypothesis. Ecotox Environ Safe 1995;31:23-8.

Warne MSJ, Schifko AD. Toxicity of laundry detergent components to a freshwater cladoceran and their contribution to detergent toxicity. Ecotox Environ Safe 1999;44:196-206.

Wen X, Du Q, Tang H. Surface complexation model for the heavy metal adsorption on natural sediment. Environ Sci Technol 1998;32:870-5.

$\mathrm{Xu}$ FL, Jorgensen SE, Tao S. Ecological indicators for assessing freshwater ecosystem health. Ecol Model 1999;116:77-106.

Yang R. Toxicology of chemical mixtures - case studies, mechanisms, and novel approaches. Academic Press, San Siego; 1994.

R.N.Yong RN, A.M.O.Mohamed AMO, B.P.Warkentin BP. Principles of contaminant transport in soils. Amsterdam: Elsevier; 1992a.

Yong RN, Mohamed AMO, Warkentin BP. Principles of contaminant transport in soils. Elsevier, Amsterdam; 1992b.

T.Zurmühl T, W.Durner W. Modeling transient water and solute transport in a biporous soil. Water Resour Res 1996;32:819-29. 